NBER WORKING PAPER SERIES

\title{
LIFE-CYCLE CONSUMPTION PATTERNS AT OLDER AGES IN THE US AND THE UK: CAN MEDICAL EXPENDITURES EXPLAIN THE DIFFERENCE?
}

\author{
James Banks \\ Richard Blundell \\ Peter Levell \\ James P. Smith \\ Working Paper 22513 \\ http://www.nber.org/papers/w22513 \\ NATIONAL BUREAU OF ECONOMIC RESEARCH \\ 1050 Massachusetts Avenue \\ Cambridge, MA 02138 \\ August 2016
}

The research reported in this paper was not the result of a for-pay consulting relationship. Further, none of the authors nor their respective institutions have a financial interest in the topic of the paper that might constitute a conflict of interest. This research was supported by grants from the National Institute on Aging and the ESRC Centre for the Microeconomic Analysis of Public Policy at IFS. The authors would like to thank David Rumpel and Iva Maclennan for expert research assistance with the preparation of the NHIS and Brendan Williams for help constructing price indices for the US. The authors are grateful for comments from Michael Hurd, David Laibson and other attendees at the NBER economics of aging meeting in Boulders Arizona. The views expressed herein are those of the authors and do not necessarily reflect the views of the National Bureau of Economic Research.

NBER working papers are circulated for discussion and comment purposes. They have not been peer-reviewed or been subject to the review by the NBER Board of Directors that accompanies official NBER publications.

(C) 2016 by James Banks, Richard Blundell, Peter Levell, and James P. Smith. All rights reserved. Short sections of text, not to exceed two paragraphs, may be quoted without explicit permission provided that full credit, including $(\odot$ notice, is given to the source. 
Life-Cycle Consumption Patterns at Older Ages in the US and the UK: Can Medical Expenditures Explain the Difference?

James Banks, Richard Blundell, Peter Levell, and James P. Smith

NBER Working Paper No. 22513

August 2016

JEL No. D10,D11,D12,D14,D91

\begin{abstract}
$\underline{\text { ABSTRACT }}$
In this paper we document significantly steeper declines in nondurable expenditures in the UK compared to the US, in spite of income paths being similar. We explore several possible causes, including different employment paths, housing ownership and expenses, levels and paths of health status, number of household members, and out-of -pocket medical expenditures. Among all the potential explanations considered, we find that those to do with healthcare-differences in levels and age paths in medical expenses-can fully account for the steeper declines in nondurable consumption in the UK compared to the US.
\end{abstract}

James Banks

Arthur Lewis Building-3.020

School of Social Sciences

The University of Manchester

Manchester M13 9PL

United Kingdom

and Institute for Fiscal Studies

j.banks@ifs.org.uk

Richard Blundell

University College London

Department of Economics

Gower Street

London, ENGLAND

r.blundell@ucl.ac.uk
Peter Levell

Institute for Fiscal Studies

7 Ridgmount Street

London WC1E 7AE

peter_1@ifs.org.uk

James P. Smith

RAND Corporation

1776 Main Street

P.O. Box 2138

Santa Monica, CA 90407-2138

smith@rand.org 


\title{
Life-Cycle Consumption Patterns at Older Ages in the US and the UK: Can Medical Expenditures Explain the Difference?
}

\author{
James Banks, Richard Blundell, Peter Levell, and James P. Smith*1
}

July 2016

\begin{abstract}
In this paper we document significantly steeper declines in nondurable expenditures in the UK compared to the US, in spite of income paths being similar. We explore several possible causes, including different employment paths, housing ownership and expenses, levels and paths of health status, number of household members, and out-of pocket medical expenditures. Among all the potential explanations considered, we find that those to do with healthcare-differences in levels and age paths in medical expenses - can fully account for the steeper declines in nondurable consumption in the UK compared to the US. (JEL D10, D11, D12, D14, D91)
\end{abstract}

Research on life cycle consumption patterns has typically concentrated on working ages with an emphasis on expected paths in labor income, economic wage shocks, and retirement; see for example the Review of Economic Dynamics special issue on micro facts (Violante 2010). However, this leaves out an important and growing span of life during the post-retirement years where other factors such as health, mortality, health expenses and shifts in housing expenditures and recreation may play a more central role. Moreover, these are areas where there are large cross-country institutional differences - for example in housing markets and in whether medical care is privately or government financed - that may have important implications for patterns of nondurable consumption at older ages.

\footnotetext{
"Banks: Institute for Fiscal Studies, 7 Ridgmount Street, London WC1E7AE, United Kingdom and University of Manchester, Oxford Road, Manchester M139PL, United Kingdom (e-mail: j.banks@ifs.org.uk); Blundell: Institute of Fiscal Studies, 7 Ridgmount Street, London, WC1E7AE and University College London, 30 Gordon Street, London WC1H0AX, United Kingdom (e-mail: r.blundell@ucl.ac.uk); Levell: Institute of Fiscal Studies, 7 Ridgmount Street, London WC1E7AE, United Kingdom and University College London, 30 Gordon Street, London WC1H0AX, United Kingdom (e-mail: peter_1@ifs.org.uk); Smith: RAND Corporation, 1776 Main Street, PO Box 2138, Santa Monica, CA 90407 (e-mail: smith@rand.org). The research reported in this paper was not the result of a for-pay consulting relationship. Further, none of the authors nor their respective institutions have a financial interest in the topic of the paper that might constitute a conflict of interest.

${ }^{1}$ This research was supported by grants from the National Institute on Aging and the ESRC Centre for the Microeconomic Analysis of Public Policy at IFS. The authors would like to thank David Rumpel and Iva Maclennan for expert research assistance with the preparation of the NHIS and Brendan Williams for help constructing price indices for the US. The authors are grateful for comments from Michael Hurd, David Laibson and other attendees at the NBER economics of aging meeting in Boulders Arizona.
} 
In this paper we show that in the UK average nondurable expenditure between the ages of 45 and 75 falls by around 2 percent each year. This compares to 1.3 percent for the United States. To illustrate, the first panel of Figure 1 plots nondurable expenditures in the UK and US by age averaged across birth cohorts. It's clear that spending remains roughly constant after age 50 in the US while it falls much more rapidly in the UK.

What can explain a difference of this magnitude? An obvious starting point is to examine age paths of income to access the extent to which consumption expenditures are tracking age paths in household income. But the second panel in Figure 1, which plots cohort averaged paths of household income at older ages in the two countries, demonstrates that, if anything, incomes decline at a slightly faster rate in the US than the UK. This therefore seems unlikely to be the major reason for a flatter spending profile in the US. In this paper we investigate other possible reasons that may explain the dramatically different patterns of nondurable consumption of older ages in the two countries by investigating differences in both inter and intra-temporal consumption for households around and beyond retirement age.
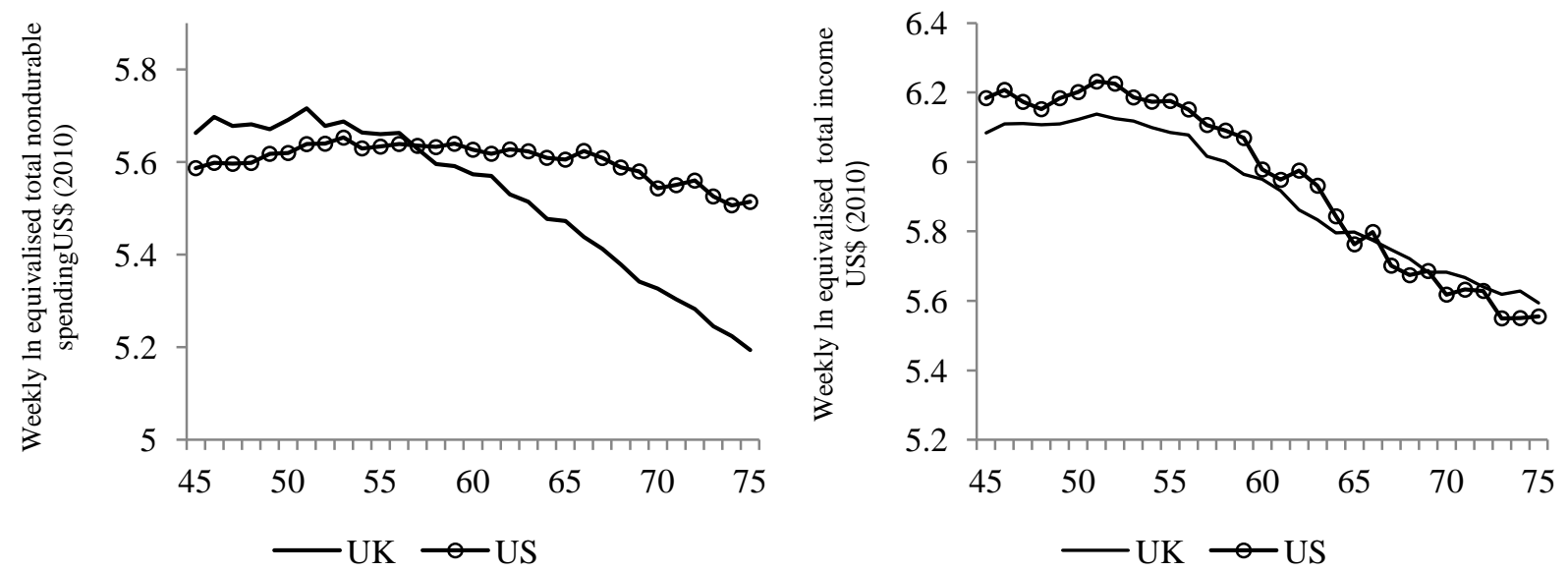

Figure 1. Nondurable Spending and Incomes in the US and UK by Age, 1984-2010

Note: Authors' calculations using BLS Consumer Expenditure Survey 1984-2010 and ONS Living Costs and Food Survey 1984-2010. Values are in US\$ (2010). Figures equivalized using the modified OECD scale.

The set of factors that we explore in this paper include: differential cohort effects in the two countries that may distort average life-cycle age profiles, differences in timing of retirement in the presence of separabilities with employment, differential paths of housing expenditures possibly driven by institutional differences in housing markets between countries, level and path differences in health status and mortality, and finally levels and volatility of medical spending in the US as deteriorating health with age leads to higher spending there while this is not true in the UK because of the National Health Service (NHS). 
Our empirical strategy is to first quantify cross-country differences in three potential factors - employment, housing status and health — and look for any immediate differences that might explain the differential consumption paths observed in Figure 1. We find, however, that most of these variables evolve in a similar way in both countries although there are some notable differences in tenure status. But even in the absence of differences in profiles, these three factors could play a role in explaining the different shape of spending profiles if there are differences in the nature of non-separabilities between these variables and consumption expenditures across the two countries. Hence, we move on to look for evidence of such non-separabilities by examining their effect on within-period budget allocations in a simple demand system estimated in each of the two countries. We find evidence that the relationship between health expenditures and mortality and employment is much stronger in the US, suggesting that a model of non-durable non-medical spending paths might display more similarities across countries.

We next consider inter-temporal profiles and non-separabilities by estimating a model of consumption growth. We find that removing medical expenditures accounts for just under three quarters of the difference between the two countries.

The rest of the paper is organized as follows. In the next section we describe in more detail the essential features of the data we assemble to look at these issues and document cohort specific paths of nondurable spending and household income for both countries. We then move on to look at various potential explanations for the cross-country differences in turn. To illustrate, Section II provides a description for cohort specific age paths in employment in the two countries and discusses their implications for consumption profiles, Section III provides a parallel treatment for housing by describing age paths of housing ownership and Section IV focuses on levels and paths of health status and differential levels and age patterns of medical expenditures. We then estimate within-period and inter-temporal models of non-durable spending patterns in each country that incorporate these factors in order to explore their role. Section V contains within-period demand models for the various sub-components of total nondurable expenditure conditioning on factors just discussed. Section VI presents results obtained from an inter-temporal model of growth rates in total nondurable expenditures for each country to identify factors that may account for different shaped consumption paths at older ages. The final section highlights our major conclusions. 


\section{The Life-Cycle Pattern of Consumption and Income}

We use two repeated cross-sectional surveys widely viewed as containing the highest quality measurement of household expenditure and its components in each country - the Consumer Expenditure Survey (CEX) in the US and the Living Costs and Food Survey (LCFS) in the UK. While these surveys do not cover the same individuals for long periods of time, we organize the data to create a pseudo-panel and track cohort consumption behavior by age (in the manner of Browning, Deaton, and Irish (1985)). To do this we group individual observations by 5-year birth cohorts and take averages within each year. Cohorts are determined by the age of the household head. Following this approach allows us to merge in information from other surveys at the cohort-year level where necessary.

The LCFS is an annual cross-sectional survey that has been running in one form or another since 1961. The LCFS, formerly known as the Family Expenditure Survey, is conducted by the Office for National Statistics (ONS), the UK's national statistical agency and has been the basis of a number of studies of intra- and inter-temporal spending patterns. Currently it interviews around 6,000 households throughout the UK and continuously throughout the year. The survey begins with an interview with questions about demographic characteristics, income, large purchases over the last year and regular expenditures (such as magazine subscriptions, internet subscription costs and so on). Each household member over 16 then records all spending in a diary over the next two weeks.

For the US we make use of the Consumer Expenditure survey (CEX). This survey has carried out by the Bureau of Labor Statistics (BLS) on a continuous basis since 1980. For some quarters prior to 1984, the survey only covered households living in urban areas. The CEX includes two separate surveys, a diary survey which works much like the LCFS, and an interview survey, where households are asked to recall their spending on a range of spending categories over the previous three months. The interview survey is also a short panel, as the same households are interviewed on up to 5 occasions. The first of these interviews collects some basic data on family characteristics. Each subsequent interview updates this information and asks questions concerning household spending over the previous 3 months. Information on incomes and labor force participation are however only collected in the $2^{\text {nd }}$ and $5^{\text {th }}$ interviews (except for new household members and members who have newly started work), meaning that income and spending data for the $3^{\text {rd }}$ and $4^{\text {th }}$ interviews need not cover the same time periods. In this paper we only make use of the interview survey. Around 5-8000 households are interviewed in each quarter. 
In both UK and US surveys, spending data are provided for hundreds of highly disaggregated individual product codes. We allocate these goods into 8 broader categories defined to be consistent across the two countries: food in, food out, other nondurables, medical, housing related, recreation and transport and durables. Some examples of what are included in these categories are given in Table 1. We do not include rental payments or mortgage interest in any of these definitions as we do not observe the "shadow price" of owned housing in the LCFS, nor can we estimate it easily (The CEX does include an selfreported imputed rental costs for owned properties). We define total nondurable expenditures to include all rows in Table 1 with the exception of the final row measuring durable spending.

Table 1. Spending Categories

\begin{tabular}{ll}
\hline Food in & Food at home \\
Food out & Food in restaurants, school dinners, catering. \\
Other nondurables & $\begin{array}{l}\text { Alcohol, tobacco, clothes, books, tobacco, } \\
\text { child care, pet goods and services. }\end{array}$ \\
Medical & $\begin{array}{l}\text { Health insurance premia, fees for services from } \\
\text { health professionals, drugs, medical equipment, } \\
\text { care in nursing homes, care of invalids. }\end{array}$ \\
Housing related & $\begin{array}{l}\text { Electricity, gas and water bills, domestic } \\
\text { services, repairs, building insurance. }\end{array}$ \\
Recreation & $\begin{array}{l}\text { Sporting goods, musical instruments, CDs, } \\
\text { entertainment, holidays }\end{array}$ \\
Transport & $\begin{array}{l}\text { Motoring costs, petrol, fares for public } \\
\text { transport, air fares. }\end{array}$ \\
Dehicles, white goods, black goods.
\end{tabular}

Household income data are derived from the same surveys and cohort age profiles obtained in the same manner. Household income is defined comprehensively to include all sources of income for the head of household, the spouse/partner, and all other household members net of taxes. US expenditures and incomes are deflated to 2010 terms using the Consumer Price Index (CPI). UK variables are deflated to 2010 terms using the Retail Prices Index and then converted into dollars using PPP exchange rates for that year taken from the OECD. Both surveys contain measures of standard definitions of labor force participation. From 1994 onwards, the CEX also contains detailed questions on the nature of households' health insurance policies and Medicare coverage. In both datasets we restrict out attention to households aged $45-75$. 
To control for measurement error and impacts of extreme values on life-cycle paths, we trim households in the top or bottom 1 percent of distribution of income and expenditure. In the CEX we take data from 1984 (so as to consistently include a nationwide sample) until 2010. For the LCFS we take data from 1978 until 2010. In both cases we stop in 2010 as we do not have mortality data for either country after this date.

To understand whether the patterns in Figure 1 are driven by cohort effects, Figures 2 and 3 shows how spending and incomes decline within cohorts in the two countries. Before plotting these, we remove average differences across cohorts by regressing spending and income on cohort dummies and taking the residuals. It is clear that cohort effects by themselves cannot account for the main puzzle with which we motivated this paper. The relatively flat age pattern of non-durable consumption at older ages in the USA compared to the much more steeply declining age declines in the UK is also apparent for individual cohorts. Within cohort declines in incomes also remain similar across the countries. ${ }^{2}$
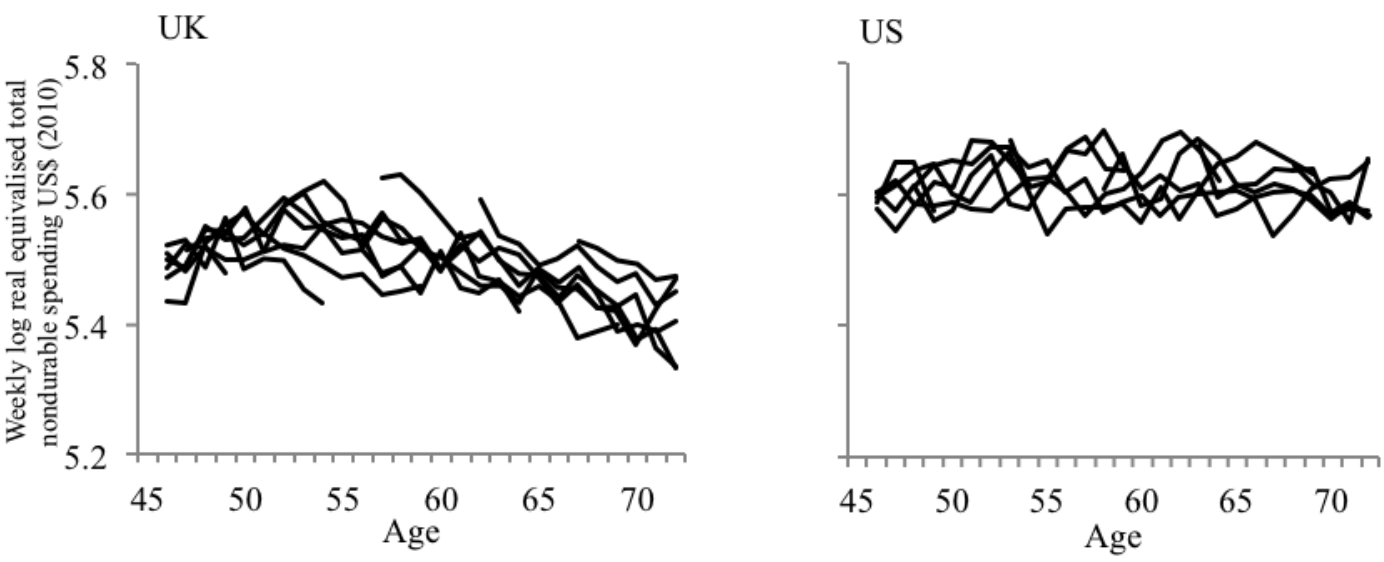

Figure 2. Nondurable Spending by Cohort and Age

Note: Data from LCFS in the UK and CEX for the US. Each line represents average log nondurable expenditures at each age for 5-year birth cohorts over the periods they are observed between ages 45 and 75 over the period 1984-2010. Average differences across cohorts are removed by regressing spending on cohort dummies and taking the residuals. Values are in US\$ (2010). Figures equivalized using the modified OECD scale.

\footnotetext{
${ }^{2}$ In the CEX there were two changes to the way incomes were measured that matter for Figure 3. One occurred in 2001 and the other in 2004. The first introduced a bracketing question for those who did not report their incomes first time round. The second introduced imputation for non-responders. The income definition we employ makes use of non-bracketed responses only from 2001 and non-imputed values for income from 2006 onwards. In 2004 and 2005 it is not possible to remove non-imputed income values.
} 

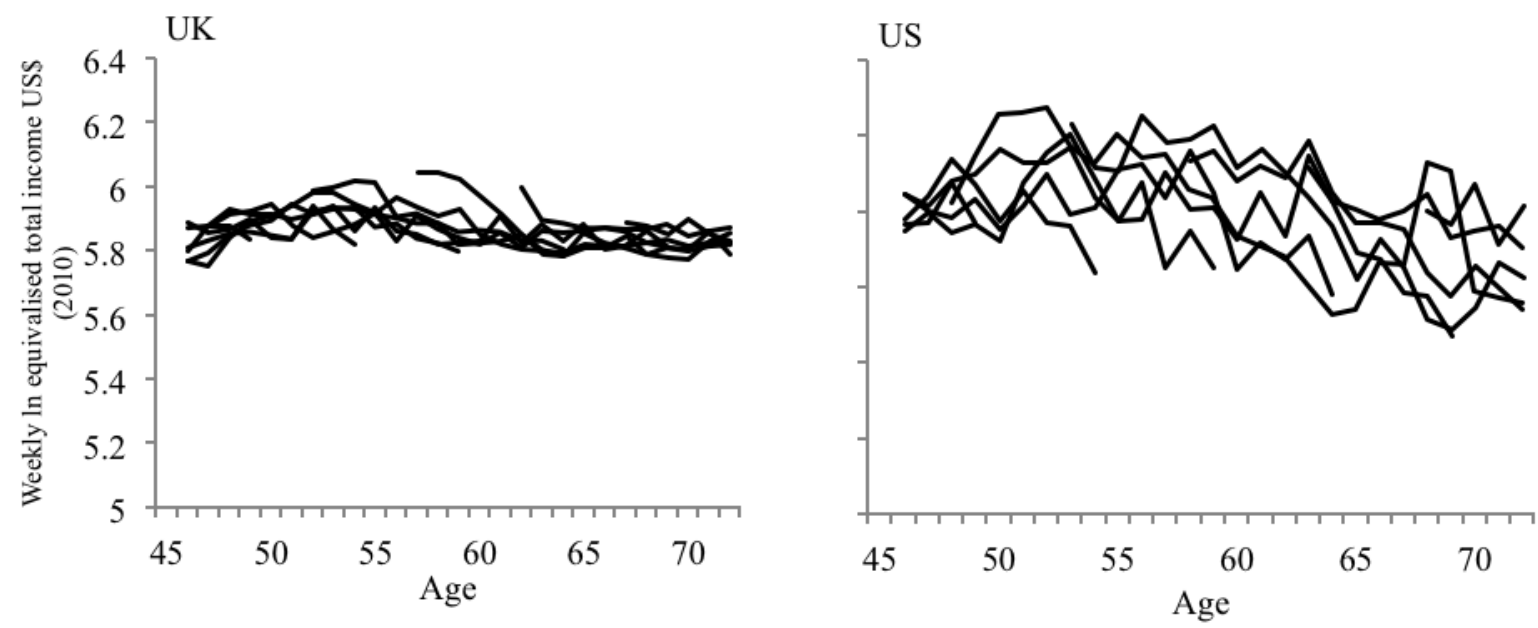

Figure 3: Log Household Income by Cohort and Age

Note: Data from LCFS in the UK and CEX for the US. Each line represents average log incomes at each age for 5- year birth cohorts over the periods they are observed between ages 45 and 75 over the period 1984-2010. Average differences across cohorts are removed by regressing incomes on cohort dummies and taking the residuals. Values are in US\$ (2010). Figures equivalized using the modified OECD scale.

\section{Differences in Employment and Retirement}

One dimension of labor force behavior at older ages that has been studied in the context of consumption age profiles involves the impact of retirement on levels and time paths of consumption. Consumption levels and paths may not be independent of the retirement decision if preferences over employment and consumption are not separable, or individuals do not fully anticipate income reductions coincident with labor market retirement, (Banks et al. 1998). The importance of this in explaining consumption trajectories at older ages is substantial. In the US, it has been estimated that work related expenditures account for the entire decline in nondurable spending from middle age to age 75 (Aguiar and Hurst, 2013). In addition to any direct costs associated with work, movements out of employment may also be associated with having more time to spend shopping for discounts or for home production of some goods (Aguiar and Hurst, 2007). This could partially explain crosscountry differences if there are differences in the links between labor supply and consumption expenditures in the two countries, or if declines in employment were more rapid in one country than another (or both).

We illustrate age patterns of labor force participation by age in Figure 4 for men in both countries. Male age patterns of employment are clear with steady declines in participation from almost ninety percent to relatively small rates of participation by the midsixties. 

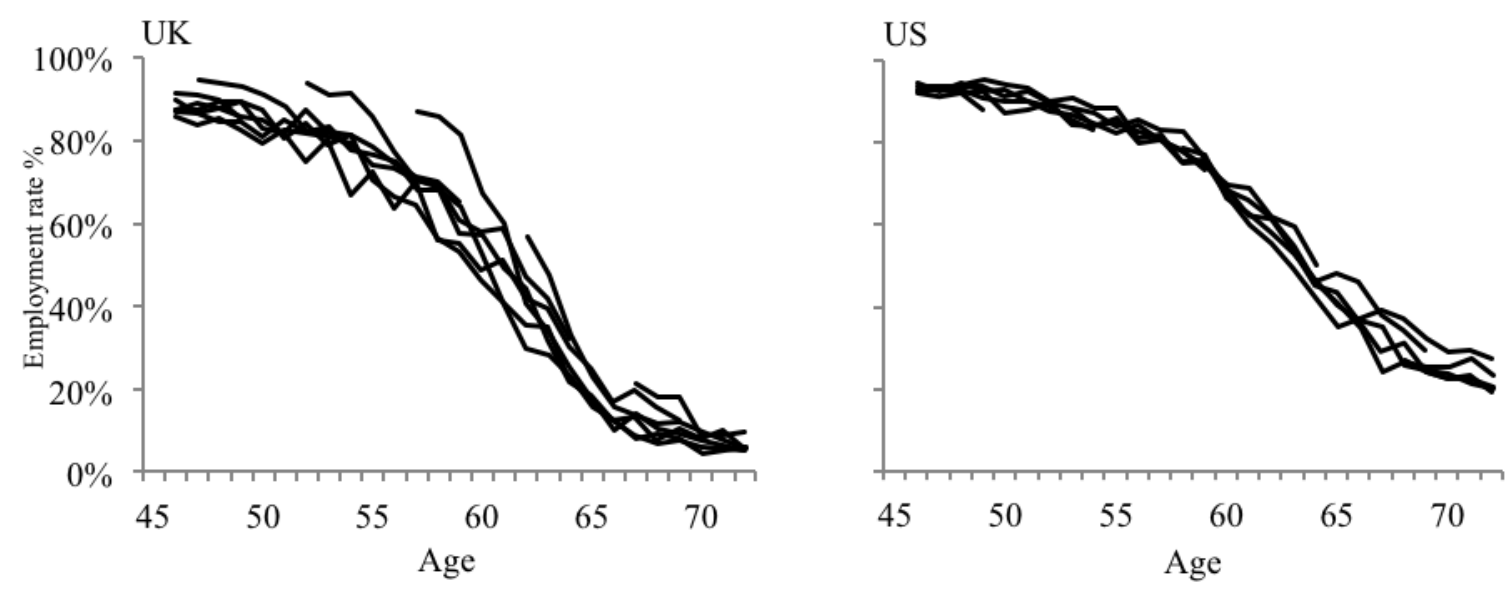

Figure 4. Employment Rates: Men by Cohort and Age

Note: Data from LCFS in the UK and CEX for the US. Each line represents average employment rates for men at each age for 5-year birth cohorts over the periods they are observed between ages 45 and 75 over the period 1984-2010.

These declines in male employment by age are somewhat more rapid in the UK compared to the United States, but the main message would be that they are quite similar. Age paths for women (not shown) also display the same pattern of rapid declining employment rates with age as women exit the labor force in both countries.

In the absence of non-separabilities in employment and consumption, differences in paths of employment at older ages in the two countries do not seem large enough to be the major explanation for the substantial differences in consumption profiles. Non-separabilities can be important and we will examine the role of non-separabilities between labor supply and consumption in explaining the cross-country difference in consumption profiles in more detail in Sections V and VI below. We also discuss the important relationship between employment and medical expenses in the United States further in Section IV.

\section{Housing Ownership and Downsizing}

Housing related decisions and expenditures represent another spending category in which there are important institutional differences between the countries that may affect levels and age paths of expenditures at older ages. We have provided evidence in other work that there exists far less geographical mobility in Britain compared to the United States and more downsizing in the US compared to the UK as a meaningful fraction of older Americans move to smaller homes (i.e., fewer rooms) with little evidence of such downsizing in Britain (Banks et al. 2010; 2012). While this lower rate of British mobility was characteristic of both owners and renters, the differential was particularly high among renters indicating that higher transactions costs associated with owning are unlikely to be a full explanation. 
For British households over age 50, the probability of being a homeowner is about thirteen percentage points lower than for an American household, a deficit mostly offset by a higher probability of renting in highly subsidized 'social' housing. The major secular changes in housing tenure at older ages have decidedly taken place in the UK and not the US. The fraction of older British people owning their own home increased by almost thirty percentage points (from less than half to over 80 percent) from the 1908-12 cohort to the 1943-47 cohort. In contrast over the same set of birth cohorts and age groups, the fraction of older American households who were home owners has remained relatively stable at around 80 percent.

The primary reason for this secular change in home ownership rates for older British households is due to changes in the proportion of individuals in social housing. In the UK there is a system of subsidized housing, often referred to as local authority, social or council housing. Those who are allocated a property pay a below-market rent, and the landlord will be either the local authority or a housing association. Individuals entitled to such a rental property are placed on a waiting list until suitable accommodation becomes available. While entitlement to live in social housing is subject to a strict means test, once allocated a property, tenants can usually stay for life irrespective of any changes in circumstance. Social renters have a severely reduced incentive and ability to move or to downsize their property, for several reasons. Even if a tenant's current circumstances mean that they are still entitled to social housing, moving can be very difficult because of shortages of social housing. Existing tenants are treated the same as new applicants, so if they are not in a priority group, they may not be allocated a different property. For those whose circumstances have changed in such a way that they would no longer be entitled to social housing if they were to reapply, there is a large incentive not to move as they may not be allocated a different property at all and may have to move into the private sector and pay full market rent.

There has been a sharp across cohort decline in social rental housing in the UK that parallels the increase in home ownership across cohorts (which for space considerations we do not plot). There was an almost 30 percentage point decline in the fraction of British households in social rental housing, which is pretty much the same percentage point increase observed in home ownership. Over the same set of birth cohorts, ages, and years there was little change in the fraction of households in private rental housing. These changes reflect the introduction of a 'Right-to-buy' in 1980 which required local authorities to sell councilowned housing at a discount to eligible tenants (the policy was later extended to other forms of social housing). 
The final important set of patterns in housing to consider refer to an differential downsizing in the two countries at older ages. Downsizing refers to the size of dwellings in which one lives. In a recent paper (Banks et al. 2010), we showed that downsizing, as proxied by number of rooms, was much more common and larger in the United States compared to the UK. The absence of downsizing in the UK was largely due to the considerably smaller geographically mobility in the UK-among those households who did move the reduction in number of rooms was similar in both countries.

\section{Health and the Divergence of Medical Expenditures}

Our health measures are based on self-reported health status, age specific mortality rates, and out-of-pocket medical expenditures by cohort, age, and gender. Neither the CEX nor LCFS include information on health or mortality, so we draw these from other sources, For the UK health status data come from two cross-sectional surveys, the Health Survey for England (HSE) and the General Household survey (GHS). These surveys contain information on household's self-reported health which we average by age, sex and cohort. Two surveys are used as we do not have GHS data after 2006, and HSE data before 1991. GHS data are used up to 1997 and HSE from 1997 onwards.

\section{A. Health Status}

In the GHS respondents are asked about their general health status over the last 12 months which they answer on a three point scale: answers can be "Good", "Fairly good", or "Poor". In the HSE, households are asked to report their general health on a 5 point scale "Very good", "good", "fair", "bad", or "very bad". For consistency we group these into three categories (by putting the final three responses into a single "worst health" group). We then average health status by age, year, and sex and use this information to impute health of household heads in the LCFS. We also compute the average health of the spouse of someone of a given age and sex in each year and use this to assign health status of spouses. To this we add data on mortality rates by age, sex and cohort/year from the ONS Mortality tables.

For the US we use the National Health Interview Surveys (NHIS). NHIS is an ongoing nationwide survey of about 40,000 households. Since 1982, NHIS used a 5 point scale to measure respondents' general health status "Would you say your health in general was excellent, very good, good, fair, or poor?" We create three categories for consistency with our UK measure. These three groups are "excellent" or "very good", "good", and "fair" or "poor". We use these to impute health statuses to household heads and spouses in the CEX 
in the same way we do for the LCFS. We also calculate the proportion of responses that are self-reported in each cell to use as a control. Mortality data for the United States are obtained from the Berkeley life tables which also give death rates by age, gender and year (http://www.demog.berkeley.edu / bmd/states.html ).

Figure 5 plots proportions of those in worst health in both countries showing several distinct patterns in health status in both countries. First levels of worse health are always higher in the UK than in the US. However, these different levels of subjective health status in the UK compared to the US have been shown to be due to different subjective health thresholds between the two countries. In the age groups we are considering the British are typically healthier than the Americans with prevalence of almost all diseases higher in the US compared to the UK (Banks et al. 2006). At the same objective health levels, the British report themselves in worse health on subjective scales.

The second pattern to note in Figure 5 is that the fraction of a cohort in poor health rises with age in both countries. Between ages 45 and 70 the fraction in worse health increases by about 15 percentage points which in the US implies an almost a doubling of the fraction. These growing levels of poor health with age are no doubt understated somewhat since rising mortality with age is removing some of those in worse health from the sample as we move to the next age group.

The third pattern concerns cohort effects in these paths of health at older ages. There is little evidence of cohort differences in the UK; cohort differences are however apparent in the US. The impact of declining health on consumption decisions in a life-cycle model will depend on how it affects the marginal utility of consumption. If poor health reduces the marginal utility of consumption, then we will observe that consumption declines more steeply with age as health deteriorates. Various papers have investigated the dependence of the marginal utility of consumption on health without achieving consensus on either its sign or magnitude (see Finkelstein, Luttmer and Notowidigdo (2009) for a survey of the available literature). Lillard and Weiss (1997) find that there is substantial positive effect on marginal utility using panel data on consumption (as inferred from income flows and asset changes) and health shocks. On the other hand, using changes in subjective well-being in response to health shocks for individuals with different permanent incomes to infer the effect of health on the marginal utility of consumption, Finkelstein, Luttmer, and Notowidigdo (2008) find a substantial negative effect. Other studies have essentially found no effect. De Nardi, French and Jones (2010) estimate a model allowing preferences over consumption to be health dependent. They find that the parameter governing the effect of health on the marginal utility 

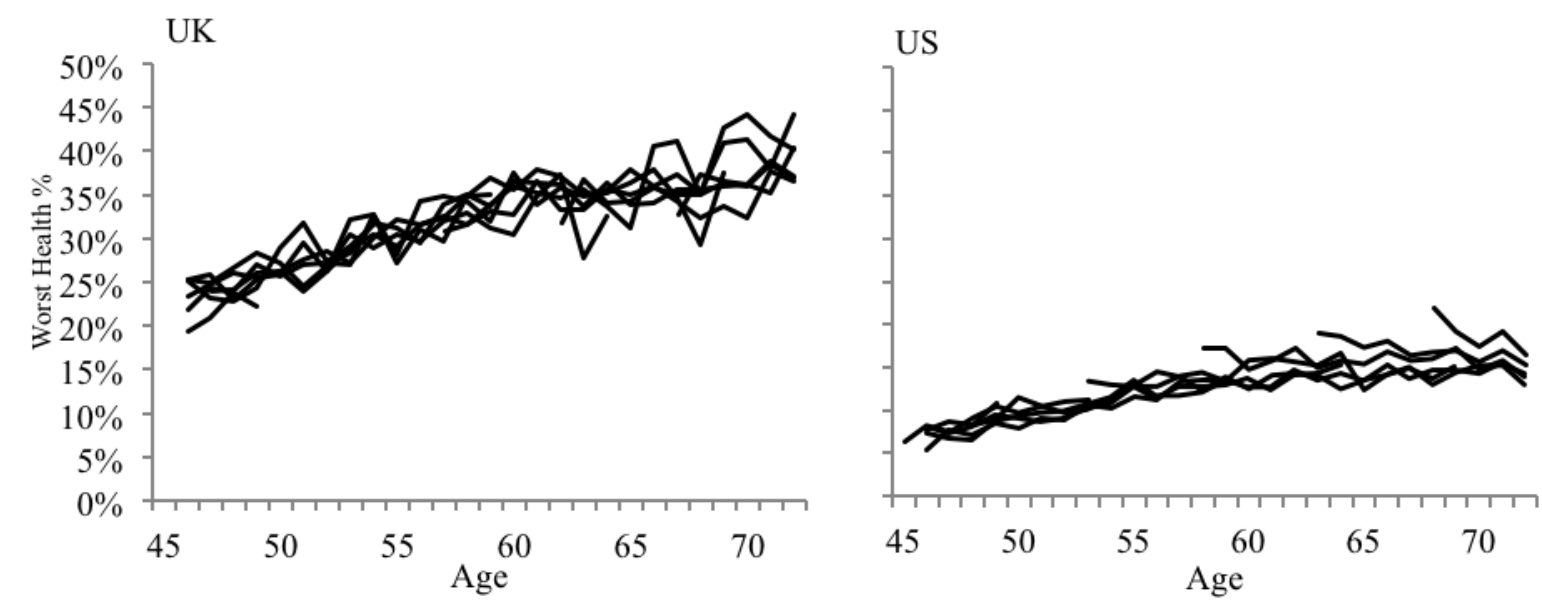

Figure 5. Proportion of Responders in Worst Health by Cohort and Age

Note: Data for the UK is from the HSE and GHS surveys spliced together (adjusted to remove discontinuity between the surveys). Data for the US is from the NHIS. Each line represents proportion of household heads reporting being in the worst health condition at each age for 5-year birth cohorts over the periods they are observed between ages 45 and 75 over the period 1984-2010.

is negative but statistically insignificant. The age paths of worse health in Figure 5 seem similar in the two countries so differential declining health at older ages does not appear to be a likely reason for different paths of nondurable consumption in the two countries in Figure 1.

\section{B. Age Paths of Mortality}

In the standard life cycle model, higher age specific mortality risk acts like a decline in the interest rate encouraging current consumption and producing a steeper decline in consumption with age. Mortality risk rises steeply with age in both countries with mortality risk about ten times larger at age 70 compared to age 45 . There appears to be evidence of cohort improvements in mortality that are larger in the UK compared to the US. Due to considerations of space, we do not graph this. However the shape of the age mortality risk function appears to be similar in the two countries suggesting once again that differential mortality risk by age does not appear to be the likely source of the significantly differently age shapes in consumption in the two countries documented in Figure 1 (Hurd, 1989).

\section{Medical Expenses}

On the health side of potential explanations, we have so far explored age patterns at older ages in general health status and mortality. While both health dimensions may play a role in shaping consumption profiles at older ages their ability either alone or together to account for the much flatter nondurable consumption with age in the United States compared to the UK seems limited. The final health dimension we examine- health expenditures- 
appears to us to offer far more potential since there are large differences between the two countries. While consumption of medical services may increase in both countries as individuals age, differences in how the costs of these are financed will show up as differences in measured out-of-pocket expenditures and their dispersion.

The manner in which health costs are financed at older ages in the two countries are quite different. To a large extent, UK medical costs at all ages are paid by the state with very little absorbed by the individual. State provision not only includes medications, doctor visits, and hospitalizations but sometimes long term care costs as well (care costs may be provided by local authorities free of charge, or at subsidized rates, subject to a means test of resources). Charges are however typically levied for prescription drugs and dental care.

The situation is very different in the US where government assistance for health care is incomplete and a large proportion of the costs of medical insurance are met by employers or directly by households rather than by government. Government assistance for health care in the US is mostly provided through the Medicare ${ }^{3}$ and Medicaid programs. Figure 6 shows enrolment under the two schemes over the ages we consider. Medicare provides some insurance for the vast majority (over 90\%) of households with heads over 65 but only a
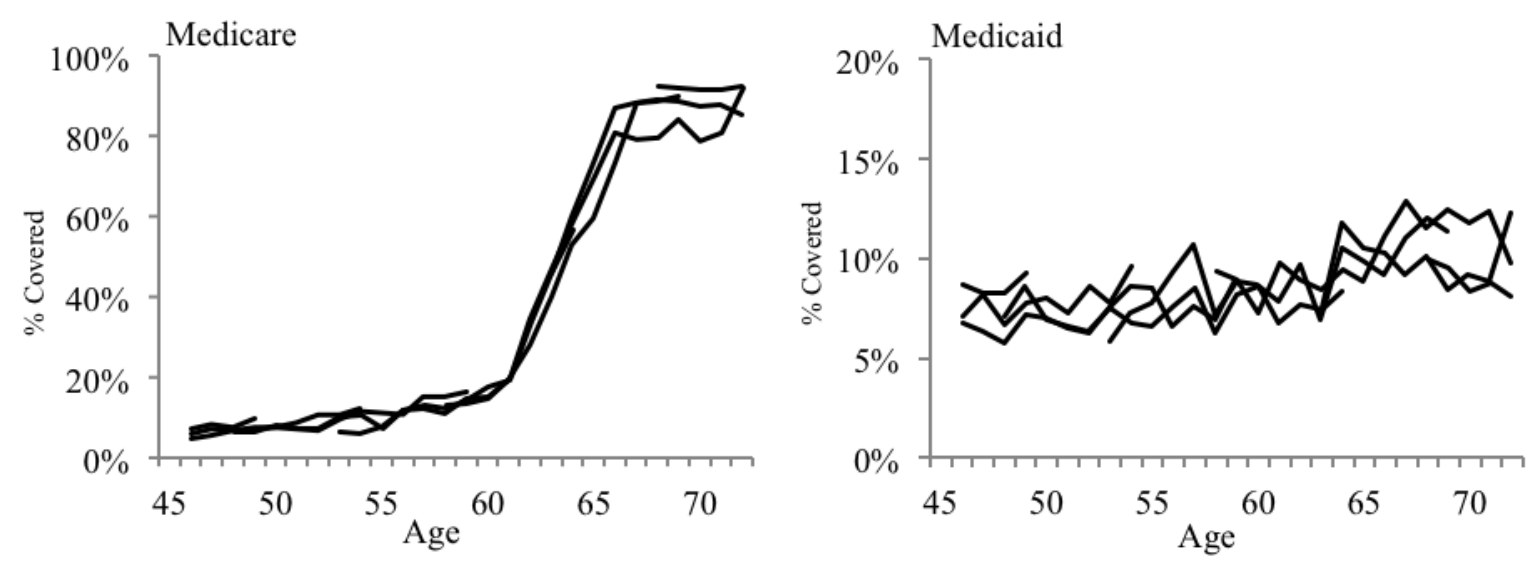

Figure 6. Proportions Covered by Government Programs

Note: Data from CEX. Each line represents proportions of households with at least one member covered by Medicare or Medicaid at each age for 5- year birth cohorts over the periods they are observed between ages 45 and 75 over the period 1994-2010.

\footnotetext{
${ }^{3}$ Medicare is a government insurance program for the elderly. Most individuals become eligible for the scheme when they turn 65. Eligibility is automatic for those who have worked and accumulated Social Security credits for at least 10 years prior to reaching this age, but those who do not meet this requirement may also qualify on the basis of their spouse's contribution history. There are however some groups who can qualify at younger ages. For example, those who have received Social Security disability benefits for at least 24 months automatically receive partial coverage. Around $12 \%$ of the population are already enrolled by the time they reach age 65 (Card et al. (2009)).
} 
limited proportion of younger households. Around $10 \%$ of households receive some assistance from Medicaid, a share which also increases somewhat (from around $7 \%$ to around $10 \%$ ) as individuals' age from 45 to 75 .

Medicare does not eliminate the need for OOP medical expenditures. Coverage is neither free nor comprehensive with various direct costs for households. While hospital insurance (Medicare Part A) is typically provided free of charge, insurance for doctor's services and prescription drugs (covered under Parts B and D) involve income-contingent premia. Individuals covered under Medicare Part C (or Medicare advantage) contract with a private company to receive their part $\mathrm{A}$ and $\mathrm{B}$ coverage and may pay a higher premium for additional coverage. In addition, Medicare does not cover the costs of all treatments and even when treatments are covered patients must pay deductibles, co-payments and co-insurance from their own resources. Importantly Medicare does not cover long term nursing care. ${ }^{4}$

There is a further institutional difference between the two countries. In the US, a large fraction of individuals have their private insurance costs covered by third parties (usually employers). This proportion tends to decline with age however as individuals retire and leave the labor market. Prior to age 65, a majority of American households have their insurance at least partially paid for by some third party but this falls to around $40 \%$ at age 70
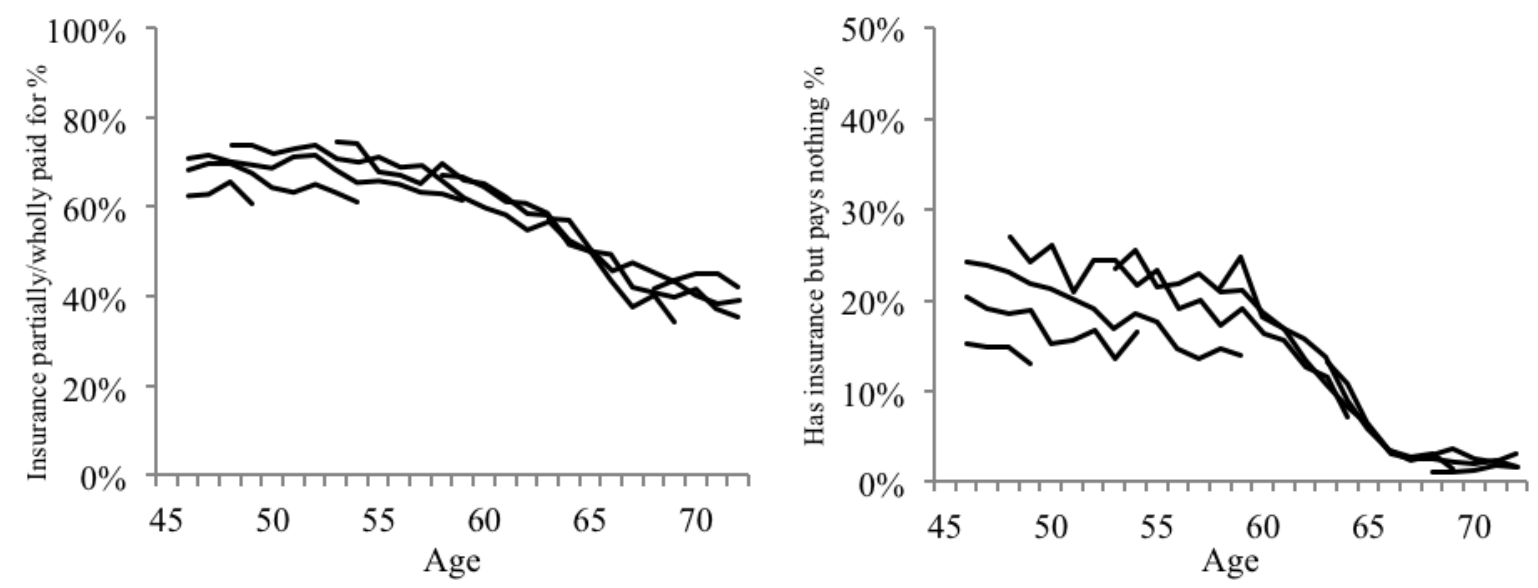

Figure 7. Insurance paid for by others US

Note: Data from CEX. Each line represents average coverage rates at each age for 5- year birth cohorts over the periods they are observed between ages 45 and 75 over the period 1994-2010. The left panel shows the proportion of households who report insurance policies wholly or partially financed by third parties. The right panel shows the proportion of households who pay no insurance costs but report being covered by insurance paid for by third parties.

\footnotetext{
${ }^{4}$ In some circumstances, treatments not covered by Medicare may be paid for through Medicaid. This is general scheme that provides reduced cost or free health services for certain low income groups, including some older households who can no longer afford the costs of their long term care. Exactly who or what is eligible varies from state to state with the federal government specifying minimum standards of coverage.
} 
as the left panel in Figure 7 shows. Similarly the proportion of households who have insurance but pay nothing (shown in the right panel of Figure 7) falls from $20 \%$ at age 45 to less than $3 \%$ at 75 . For workers the share of health costs paid by employers is substantial, at around $75-80 \%$ of the total. ${ }^{5}$

The institutions in the two countries naturally have consequences for paths of medical expenditures as individual's age. These are shown for total spending the two countries in the two panels of Figure 8. Not only are medical costs in the UK lower as a share of the budget (always under 5 percent) but there are only modest increases in this share with age. In contrast, the US graph indicates much higher and sharply rising medical costs shares at older ages in the US that are not due solely to cohort effects. To illustrate, medical costs shares in the US are approximately eight percent at age 45 and rise steadily until they are around 20 percent of total budget by age 70 .
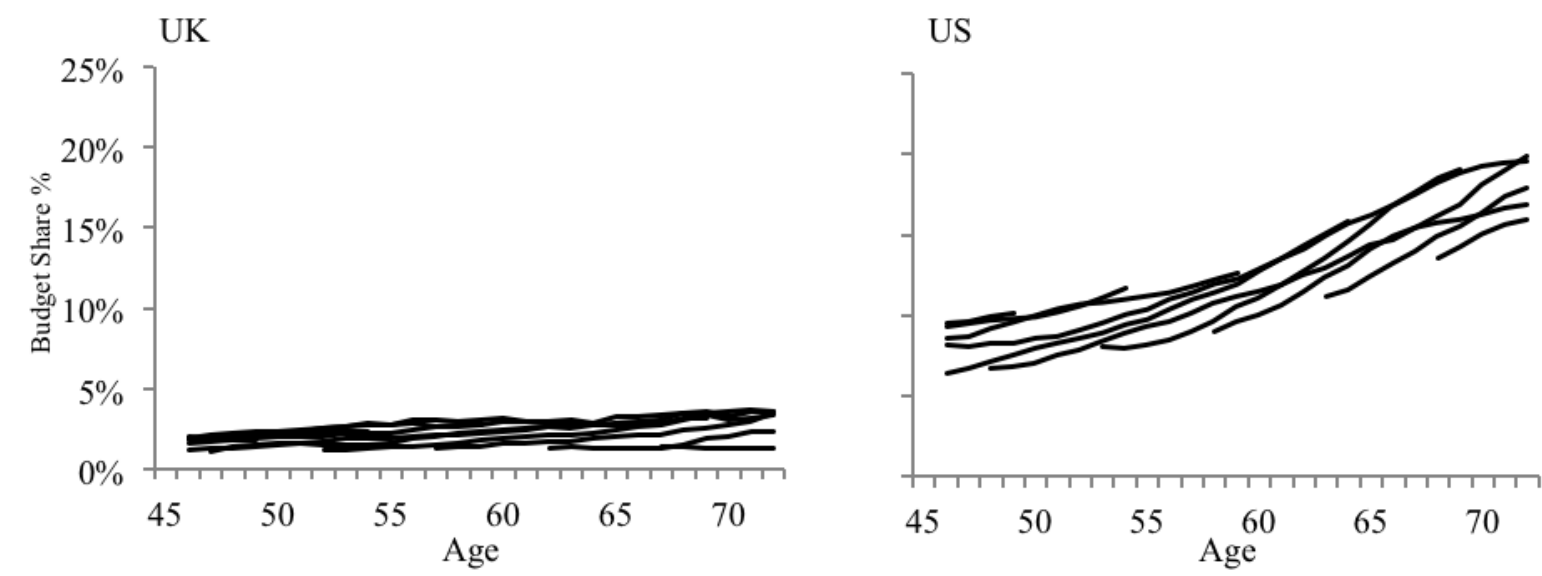

Figure 8. Share of Cohort Spending on Medical Care

Note: Data from LCFS in the UK and CEX for the US. Each line represents average budget shares out of nondurable expenditures at each age for 5-year birth cohorts over the periods they are observed between ages 45 and 75 over the period 1984-2010.

The decomposition of these medical expenditures for a single cohort is shown in Figure $9 .{ }^{6}$ In the UK, the majority of medical spending goes towards non-insurance costs. In the US insurance premia are far more important. Medicare spending begins to rise when the head reaches age 65 but the trajectory of overall spending is smooth.

\footnotetext{
${ }^{5}$ See Exhibit 4.1 in http://meps.ahrq.gov/mepsweb/data_stats/MEPSICChartbook.pdf

${ }^{6}$ Results from other cohorts are very similar.
} 

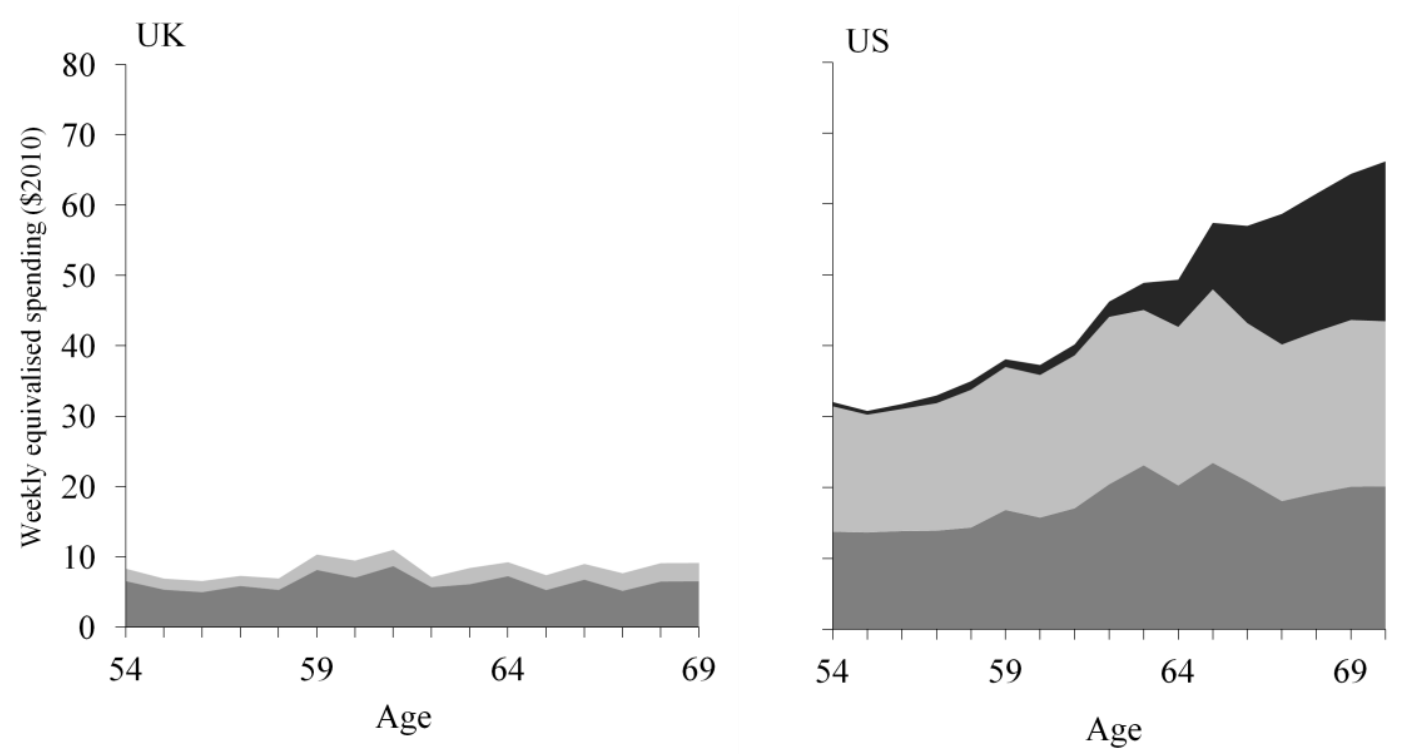

Private health insurance $\square$ Other out of pocket $\square$ Medicare

Figure 9. Composition of Medical Spending (1938-43 Birth Cohort)

Note: Data from LCFS in the UK and CEX for the US. Values shown over the period 1994-2010. Values are in US\$ (2010).

As well as being on average larger than in the UK, out of pocket expenditures in the US are also highly concentrated and persistent. Table 2 lists the distribution of all medical expenses for a population ages sixty plus in the US using the 2002, 2004, and 2006 waves of the HRS. In each of these HRS waves, respondents were asked the dollar amount of health costs that they incurred since the previous HRS wave and the nature of what these expenses were. These expenditure distributions are presented in Table 2 for a six year period between (2000-2006). For each type of medical expense, Table 2 lists means and medians as well the $25^{\text {th }}, 75^{\text {th }}, 90^{\text {th }}$, and $95^{\text {th }}$ percentiles of the distributions.

A number of salient patterns emerge. While these costs are significant with a mean of over $\$ 27,000$ over six years, there is enormous variance in costs across and within people over time. To illustrate health expenses at the $95^{\text {th }}$ percentile are around $\$ 85,000$ or almost $\$ 15,000$ per year. There is clearly for some a very real risk of very high medical expenses at these ages. While there are costs in all categories in Table 2, the sub-categories that are most important are private insurance costs and prescription drug costs which all have high means and high tails in the distributions.

In the last two columns of Table 2, we list estimated coefficients from models of wave 7 (2004) and wave 8 (2006) medical expenditures regressed on wave 6 (2002) expenditures for total out-of-pocket medical expenditures as well as for each of the expenditure subcategories. These coefficients illustrate a significant degree of persistence in medical 
expenses making their long-term costs large but also far from complete within person persistence illustrating a great deal of uncertainty and financial risk. Medical costs are included in total nondurable expenditures in Figures 1 and 2, and so may account for the slower decline in spending in the US relative to the UK. ${ }^{7}$

Table 2: US Household Medical Expenditures, 2000-2006, Age 60+

\begin{tabular}{lrrrrrrrr}
\hline & & & & & & \multicolumn{3}{c}{ Persistence } \\
Variable & Mean & P25 & Median & P75 & P90 & P95 & 2-year & 4-year \\
\hline Total & 27,668 & 6,411 & 17,312 & 36,024 & 62,520 & 84,524 & 0.658 & 0.589 \\
No insurance & 17,556 & 3,598 & 9,160 & 19,600 & 36,954 & 59,573 & 0.567 & 0.499 \\
Hospital & 1,220 & 0 & 0 & 200 & 2,000 & 5,100 & 0.215 & 0.170 \\
Nursing home stays & 2,074 & 0 & 0 & 0 & 0 & 300 & 0.416 & 0.339 \\
Outpatient & 345 & 0 & 0 & 25 & 620 & 1,750 & 0.197 & 0.149 \\
Doctor visits & 1,675 & 50 & 450 & 1,515 & 4,355 & 7,333 & 0.516 & 0.463 \\
Dental & 2,178 & 0 & 800 & 2,800 & 5,910 & 8,800 & 0.625 & 0.567 \\
Prescription drugs & 8,735 & 1,200 & 3,840 & 9,360 & 17,904 & 26,832 & 0.602 & 0.317 \\
Home health care & 161 & 0 & 0 & 0 & 0 & 0 & 0.556 & 0.107 \\
Special health facility & 81 & 0 & 0 & 0 & 0 & 200 & 0.148 & 0.144 \\
Medicare HMO & 885 & 0 & 0 & 0 & 2,712 & 5,280 & 0.282 & 0.230 \\
Private insurance & 8,286 & 0 & 3,000 & 11,568 & 24,360 & 34,560 & 0.628 & 0.544 \\
Long-term care insurance & 1,827 & 0 & 0 & 0 & 4,911 & 12,880 & 0.742 & 0.710 \\
\hline
\end{tabular}

\section{Within-period Expenditure Allocations}

In the previous sections we noted possible links between trends in demographic variables and consumption at older ages. We have highlighted differences in particular in the decline in employment, and the pattern of home ownership between the two countries. We have also noted strikingly different patterns of medical expenditures, summarized in Figure 8, largely reflecting differences in the delivery of health services in the US and the UK.

We now look more formally at possible interactions between demographic variables and consumption, which could affect the age path of consumption. Such non-separabilities may be present within period (affecting relative demands for particular goods but not the

\footnotetext{
${ }^{7}$ Of course while expenditures on medical services do not appear to increase greatly with age in the UK, consumption of such services certainly increases in both countries. This is only reflected in terms of greater personal expenditures in the US however, as in the UK these costs are borne by the state. Previous work has highlighted the distinction between consumption and expenditures when considering consumption trajectories at older ages: particularly in relation to the substitution of home production for market expenditures for food (Aguair and Hurst, 2005). Changing state provision or employer provision of some goods and services at these ages provides an additional reason to be wary of conflating the two.
} 
level of spending) or across time (affecting the inter-temporal allocation of consumption). In this section, we examine the shares of expenditure on different goods and looking for withinperiod non-separabilities. We turn to inter-temporal interactions in the next section.

We estimate an extension of the Almost Ideal specification of Deaton and Muellbauer (1980) that includes an additional quadratic term in income, (see Banks et al. (1998)). Our interest is in establishing the nature of within-period non-separabilities between consumption and housing, health and employment in the two countries through the effect of these variables on household budget shares. By including total expenditure and prices, we control for differences in trends in relative prices and wealth across different birth cohorts in the two countries, which may otherwise confound our estimates. The precise specification of the model and the estimation results are presented in Appendix A.

In both countries the demand system results show that those who rent not surprisingly spend a much smaller share of the budget on housing related expenditures. In the US the share spent on housing related expenses is 10 percentage points lower share than those who own. In the UK the equivalent number is 4 percentage points. The estimates in Table A1 of Appendix A indicate renters consequently devote higher shares to all other goods (except food at home in the US), with a particularly large effect for other nondurable spending. Owning a home outright (compared to owners who still have a mortgage to pay off) leads to small reduction in housing related expenses in both countries (though the effect is only significant at the 10 percent level in the UK).

Employment effects look as expected - in both countries when the head is employed less is spent on recreation and more is spent on food out and on transport, which is most likely associated with transport to work. Employment in the United States is associated with more food consumption both in and out of the home, but in the UK there is a substitution of food consumption to out of the home. When both head and spouse are working, there is a reduction in spending on food at home in the US.

Important differences emerge in the relationship between employment and health costs, however. In the United States where people bear more of the responsibility for paying their medical costs, head's employment reduces out of pocket medical expenses, a much larger effect than in the UK where the effect is essentially zero. Although this could partly be explained by incomplete controls for health in the model, the key difference is the association between medical insurance and being in a job in the United States (as reflected in Figure 7). In the US, the head being employed reduces the proportion spent on medical spending by 1.7 percentage points but there is no similar effect in the UK. This could reflect employers 
meeting some healthcare costs for their employees in the US (which in the UK would be met by the state). Whether the spouse works or not, does not appear to contribute to this effect.

Due to the data limitations described above, our mortality and subjective health measures capture variations in health status that occur on average at the cohort level rather than individual level variation. A higher risk of mortality among the cohort increases medical spending in both the US and UK with, perhaps unsurprisingly in light of the differential financing of medical care in the two countries, a much larger effect in the US. In the UK reductions in subjective health controlling for mortality have little effect on the composition of total household consumption (except for a reduction in spending away from home). In contrast, a worsening of the cohort's subjective health status in the United States leads to an apparent (but statistically insignificant) reduction in medical expenses once the effects of mortality are controlled for. This likely reflects some difference in health spending among cohorts that we have not been able to control for (for instance, those caused by institutional changes in Medicare coverage or changes in the availability of expensive, technologyintensive health services over time).

Comparing the positive impact of mortality probabilities on medical spending with the zero or negative effects for self-reported health suggests an Easterlin-type paradox in the relationship between subjective health measures (captured in our self-reported measures) and objective health measures (captured in our case by mortality). By this we mean that subjective measures of health may not improve even when objective measures of health do. This might occur for instance if people assess their health relative to others in their cohort (so self-reported health status would tend to vary within but not between cohorts), weakening its association with actual health conditions and so medical expenditures.

\section{Inter-temporal Allocations of Consumption}

The estimates from the previous sections have shown that health, labor supply, mortality and tenure do affect patterns of spending within any given period. Despite these factors displaying similar life-cycle profiles in the two countries, the effects on within-period spending are somewhat different in the two countries, especially in relation to medical expenditures. We now turn to our analysis of inter-temporal consumption changes controlling for such differences again tracking group level averages over time. In this section we split households into groups defined by education (whether or not the household head or their spouse completed high school), as well as year and 5-year birth cohorts. 


\section{A. Growth Rates in Consumer Expenditures}

Our demand system estimates show that there is a much greater shift towards medical spending as age increases in the US than in the UK, and this is partly arising through nonseparabilities with employment, perhaps due to the importance of employer-provided health insurance. This suggests a role for medical costs in explaining different age-profiles of total expenditure. Table 3 shows the average rates of decline in spending for nondurable goods, and nondurable goods not including medical spending within our cohort-education groups. We also show these differences for those under age 60 and for those 60 years old and older.

For the full age 45 plus population, nondurable expenditures decline by $2.17 \%$ in the UK compared to $1.34 \%$ in the US, a statistically significant difference of $0.83 \%$ between the countries ( $\mathrm{p}$-value 0.05 ). This difference in consumption expenditures before equivalization between the two countries essentially disappears when medical spending is taken out which only really affects the rate of decline in the US. This suggests that differing healthcare financing institutions may explain a significant part of the difference between the countries.

Of course, one reason consumption declines at middle and older ages is that people leave the household for several reasons which include the exit of adult children into homes of their own, divorce and the death of a spouse. This pattern is illustrated for both countries in Figure 10 which plots by age and cohort the fraction of households who contain three or more adults. These fractions decline significantly with age in both countries, especially between ages 45 and 60 continuing at a somewhat slower pace after age 60 .

Declines in the number of adults in the household will of course play a role in producing consumption declines at older ages. When we use equivalized consumption expenditures instead in part B of Table 3, not surprisingly we see that rates of decline in both measures of consumption are significantly reduced in both countries. This indicates that reductions in the number of people in the household, primarily the exit of children and death of spouses, play an important role in the rates of decline in both measures of consumption among those ages 45 and above. However, and most important, the difference between the two countries in declines in total nondurable consumption remains large and statistically significant at $0.61 \%$ (p-value 0.09). Once again this difference between the countries disappears when we examine nondurable consumption less medical expenses. 

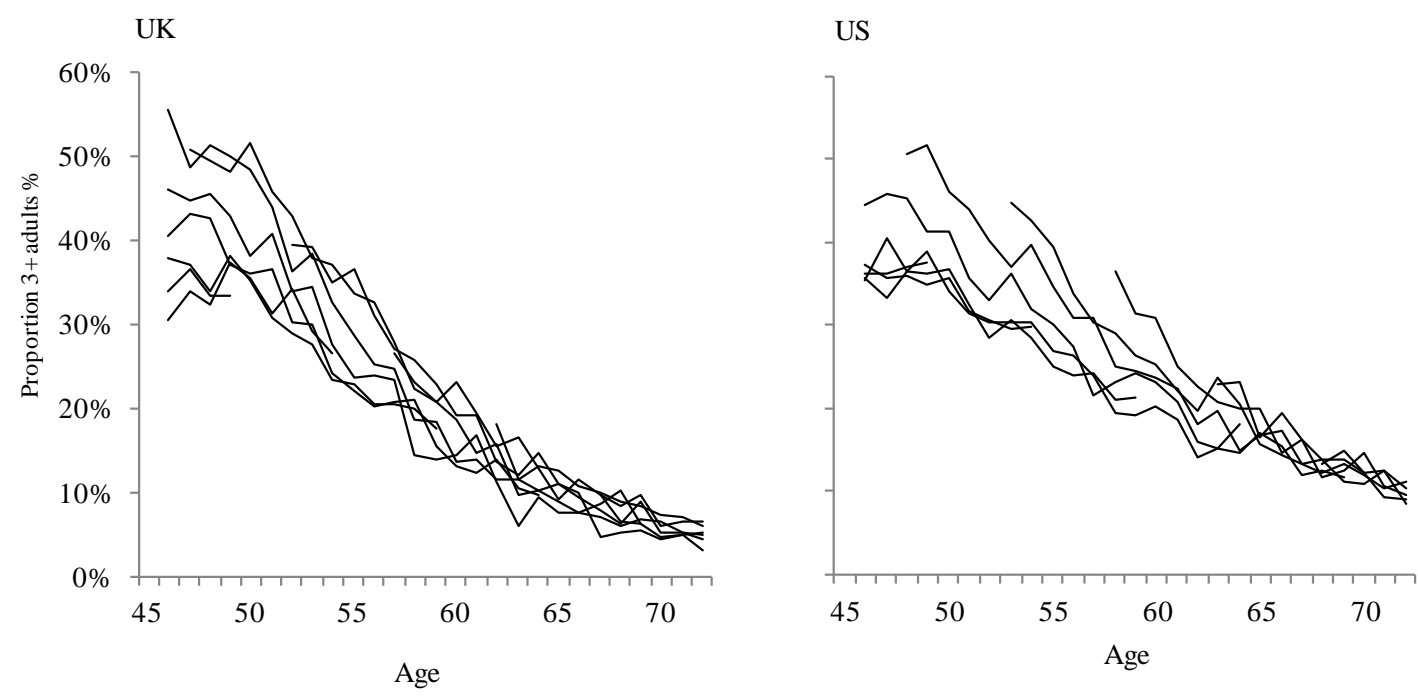

Figure 10. Proportion of Households with 3 or more Adults

Note: Data from LCFS in the UK and CEX for the US. Each line represents proportions of households with 3 or more adults (individuals over 16) for 5 - year birth cohorts over the periods they are observed between ages 45 and 75 over the period 1984-2010.

The importance of medical expenditures in shaping the relative consumption decline in the two countries is also illustrated when we separate rates of consumption decline with age into those before and after age 60. The estimated consumption difference in total nondurable consumption is significantly higher in the after age 60 group compared to those pre age 60 (0.90\% for over age 60 compared to $0.30 \%$ before age 60$)$. Once again, there is little difference between the two countries in either age group when we subtract out OOP medical expenses. The overall difference between the two countries shrinks by just under three quarters when medical spending is taken out, suggesting that differing healthcare financing institutions may explain a significant part of the difference between the countries. 
Table 3. Average Consumption Growth Rates

UK US

\section{A. Expenditure, 1984-2010}

Nondurable

$-2.17 \%$

$-1.34 \%$

$-0.83 \%$

Nondurable less medical

$-2.24 \%$

$-2.00 \%$

$-0.24 \%$

\section{B. Equivalized Expenditure. 1984-2010}

\begin{tabular}{llcc}
\hline Nondurable & $-0.55 \%$ & $0.06 \%$ & $-0.61 \%$ \\
Nondurable less medical & $-0.61 \%$ & $-0.60 \%$ & $-0.01 \%$ \\
Nondurable (Under age 60) & $-0.10 \%$ & $0.20 \%$ & $-0.30 \%$ \\
Nondurable less medical (Under age 60) & $-0.16 \%$ & $-0.23 \%$ & $0.07 \%$ \\
Nondurable (Over age 60) & $-1.04 \%$ & $-0.14 \%$ & $-0.90 \%$ \\
Nondurable less medical (Over age 60) & $-1.11 \%$ & $-1.13 \%$ & $0.02 \%$ \\
\hline
\end{tabular}

Notes: Observations weighted by cell size. Equivalized using the OECD scale. Equivalized using the OECD scale. The OECD scale is 1 for first adult, 0.5 for each additional adult and child 14 and over and 0.3 for each child under 14 .

In addition to the role of medical expenses, however, the results in the previous section also highlight the potential importance of other non-separabilities for instance relating to housing and employment. To see the extent to which controlling for differences in these and other demographic trends can explain the steeper decline in nondurable nonmedical consumption that we see in the UK we run a regression of the following form:

$$
\Delta \ln c_{s, k, t}=\alpha_{1} t+\alpha_{2} k+\gamma_{1} U S+\gamma_{2} U K+\theta \ln m_{s, k, t}+\Delta X_{s, k, t} \beta+u_{s, k, t}
$$

where $k$ denotes cohort, s denotes country and $t$ year. $c_{s, k, t}$ denotes nondurable consumption with medical expenses also removed, $m_{s, k, t}$ is the mortality rate and $X_{s, k, t}$ is a set of demographic controls. $U S$ is a dummy for the United States and $U K$ a dummy for the United 
Kingdom. ${ }^{8}$ The model contains no constant term. The difference between the coefficients $\gamma_{1}$ and $\gamma_{2}$ indicates the how much faster expenditures decline in the US relative to the UK once other factors have been controlled. We think of this as the unexplained component of the cross-country difference, and report it separately in the regression results that follow (multiplied by 100 to give a value in percentage point terms).

There may be some risk of endogeneity in estimates presented from OLS versions of equation (1). Households that move out of employment or change their tenure status may adjust their spending because these developments are responses to unexpected shocks that also lead households to reassess the value of their lifetime resources, rather than just because of non-separabilities in household preferences. As a result we also report results for IV models in which we instrument changes in employment, housing tenure, health and mortality with their first and second lags. These should be correlated with current realizations of these variables but uncorrelated with taste shifts or expectational errors that enter $u_{s, k, t} \cdot{ }^{9}$

Results for different versions of model (1) are shown in Table 4. Column (1) shows results using Weighted Least Squares (using cohort cell sizes as weights) with no controls. These results are the same as those shown in Table 3 except that to maintain comparability across regression models, we use the same sample as we will use in subsequent regressions. The difference in the average rates of decline across the two countries is around 0.8 percentage points and significant at the $10 \%$ level. In column (2) we add demographic controls for the number of children and adults in the household and a dummy for whether the household head is single. Once these are controlled for average rates of decline fall in both countries and the difference in rates of decline shrinks slightly but remains positive and significant.

Column (3) adds additional controls for employment, renter status, mortality and health, as well as linear cohort and year effects and an education dummy. These additional controls that capture possible non-separabilities once again do not appear to explain the different rates of decline. Declines in rates of employment and increases in the proportion of renters within each group are both associated with lower spending growth. The faster employment declines in the UK shown in Figure 4 therefore help account for some of the differences between the countries. However, the effect of this on the unexplained element of

\footnotetext{
${ }^{8}$ This consumption growth model differs from the standard Euler equation that are typically estimated, see Banks, Blundell and Tanner (1998), for example, in that it does not directly include the real interest rate. When included as a variable it appears that UK and US households show quite different sensitivity to interest rate changes, suggesting that it is picking up macroeconomic changes and not just differences in relative prices over time and across countries. We omit it from our analysis in what follows and include a time trend.

${ }^{9}$ We calculate lagged means excluding observations from those interviewed in the following period.
} 
Table 4. Changes in Log Nondurable Expenditures

\begin{tabular}{|c|c|c|c|c|c|c|}
\hline & \multicolumn{4}{|c|}{ Including Medical } & \multicolumn{2}{|c|}{ Excluding Medical } \\
\hline & $\begin{array}{c}\text { WLS } \\
(1)\end{array}$ & $\begin{array}{c}\text { WLS } \\
(2)\end{array}$ & $\begin{array}{c}\text { WLS } \\
(3)\end{array}$ & $\begin{array}{c}\text { WIV } \\
(4)\end{array}$ & $\begin{array}{c}\text { WIV } \\
(5)\end{array}$ & $\begin{array}{c}\text { WIV } \\
(6)\end{array}$ \\
\hline US & $\begin{array}{l}-0.013 * * * \\
(0.003)\end{array}$ & $\begin{array}{l}-0.004 \\
(0.003)\end{array}$ & $\begin{array}{l}-0.042 \\
(0.045)\end{array}$ & $\begin{array}{l}-0.046 \\
(0.051)\end{array}$ & $\begin{array}{l}-0.040 \\
(0.052)\end{array}$ & $\begin{array}{l}-0.031 \\
(0.053)\end{array}$ \\
\hline UK & $\begin{array}{l}-0.022 * * * \\
(0.003)\end{array}$ & $\begin{array}{l}-0.011 * * * \\
(0.003)\end{array}$ & $\begin{array}{l}-0.051 \\
(0.047)\end{array}$ & $\begin{array}{l}-0.056 \\
(0.053)\end{array}$ & $\begin{array}{l}-0.042 \\
(0.055)\end{array}$ & $\begin{array}{l}-0.029 \\
(0.057)\end{array}$ \\
\hline Log Mortality & & & $\begin{array}{l}-0.021 \\
(0.022)\end{array}$ & $\begin{array}{l}-0.023 \\
(0.024)\end{array}$ & $\begin{array}{l}-0.013 \\
(0.025)\end{array}$ & $\begin{array}{l}-0.006 \\
(0.027)\end{array}$ \\
\hline$\Delta$ Head employed & & & $\begin{array}{l}0.097 * * \\
(0.047)\end{array}$ & $\begin{array}{l}-0.000 \\
(0.131)\end{array}$ & $\begin{array}{l}-0.002 \\
(0.134)\end{array}$ & $\begin{array}{l}0.009 \\
(0.129)\end{array}$ \\
\hline$\Delta$ Renter & & & $\begin{array}{l}-0.443 * * * \\
(0.056)\end{array}$ & $\begin{array}{l}-0.206^{*} \\
(0.124)\end{array}$ & $\begin{array}{l}-0.252 * * \\
(0.127)\end{array}$ & $\begin{array}{l}-0.247 * * \\
(0.126)\end{array}$ \\
\hline$\Delta$ Number of kids & & $\begin{array}{l}-0.022 \\
(0.039)\end{array}$ & $\begin{array}{l}-0.015 \\
(0.042)\end{array}$ & $\begin{array}{l}-0.040 \\
(0.048)\end{array}$ & $\begin{array}{l}-0.026 \\
(0.049)\end{array}$ & $\begin{array}{l}-0.020 \\
(0.049)\end{array}$ \\
\hline$\Delta$ Number of adults & & $\begin{array}{l}0.228 * * * \\
(0.032)\end{array}$ & $\begin{array}{l}0.216 \text { *** } \\
(0.030)\end{array}$ & $\begin{array}{l}0.226 * * * \\
(0.033)\end{array}$ & $\begin{array}{l}0.227 * * * \\
(0.034)\end{array}$ & $\begin{array}{l}0.227 * * * \\
(0.033)\end{array}$ \\
\hline$\Delta$ Single & & $\begin{array}{l}-0.357 * * * \\
(0.061)\end{array}$ & $\begin{array}{l}-0.258 * * * \\
(0.059)\end{array}$ & $\begin{array}{l}-0.295 * * * \\
(0.073)\end{array}$ & $\begin{array}{l}-0.252^{* * *} \\
(0.075)\end{array}$ & $\begin{array}{l}-0.256^{* * *} \\
(0.074)\end{array}$ \\
\hline$\Delta$ Worst health & & & $\begin{array}{l}-0.208 * * \\
(0.081)\end{array}$ & $\begin{array}{l}-0.390 \\
(0.322)\end{array}$ & $\begin{array}{l}-0.394 \\
(0.331)\end{array}$ & $\begin{array}{l}-0.377 \\
(0.317)\end{array}$ \\
\hline$\pi_{t-1}^{2} \phi_{\mathrm{t}}$ & & & & & & $\begin{array}{l}0.002 \\
(0.004)\end{array}$ \\
\hline Cohort effects & $\mathrm{N}$ & $\mathrm{Y}$ & $\mathrm{Y}$ & $\mathrm{Y}$ & Y & $\mathrm{Y}$ \\
\hline Year Effects & $\mathrm{N}$ & Y & $\mathrm{Y}$ & $\mathrm{Y}$ & $\mathrm{Y}$ & Y \\
\hline Education dummy & $\mathrm{N}$ & $\mathrm{Y}$ & $\mathrm{Y}$ & $\mathrm{Y}$ & $\mathrm{Y}$ & $\mathrm{Y}$ \\
\hline$(\mathrm{US}-\mathrm{UK}) \times 100$ & $\begin{array}{l}\mathbf{0 . 8 5 0}^{*} \\
(0.437) \\
\end{array}$ & $\begin{array}{l}\mathbf{0 . 6 6 2} * \\
(0.378) \\
\end{array}$ & $\begin{array}{l}\mathbf{0 . 9 1 9} * * \\
(0.439) \\
\end{array}$ & $\begin{array}{l}\mathbf{0 . 9 6 1 *} \\
(0.512) \\
\end{array}$ & $\begin{array}{l}\mathbf{0 . 2 3 1} \\
(0.525) \\
\end{array}$ & $\begin{array}{l}\mathbf{- 0 . 1 3 2} \\
(0.751) \\
\end{array}$ \\
\hline $\begin{array}{l}\mathrm{N} \\
\mathrm{R}^{2} \\
\text { Sargan p-value }\end{array}$ & $\begin{array}{l}560 \\
0.104\end{array}$ & $\begin{array}{l}560 \\
0.336\end{array}$ & $\begin{array}{l}560 \\
0.424\end{array}$ & $\begin{array}{l}560 \\
0.322 \\
0.780 \\
\end{array}$ & $\begin{array}{l}560 \\
0.336 \\
0.820 \\
\end{array}$ & $\begin{array}{l}560 \\
0.351 \\
0.817 \\
\end{array}$ \\
\hline
\end{tabular}


the cross-country difference is offset by the larger increase in the proportion of renters in the US which other things equal imply faster spending declines there than the UK. Column (4) shows results for an IV version of the model in column (3). This reduces the size of the employment and renter coefficients but otherwise leaves our results unchanged.

In column (5) we remove medical expenditures. While this does not have a larger effect on individual coefficients, the unexplained difference in the spending growth between the two countries falls to 0.2 percentage points and is no longer significant. This figure is very similar to the estimated size of the raw difference between the two countries reported in Table 3.

Results for regressions run separately by country are presented in Appendix B. The effect on spending growth of being a renter is larger in the US. There are also differences in the effects of demographics. While the effect of going from being single to a couple is larger in the US, the effect of adding subsequent adults has larger effects on spending in the UK. Otherwise the coefficients in the two countries have a similar magnitude.

In appendix B we also show the decline in log expenditures within each category by expenditure category in Table B.3. While non-medical spending declines at similar rates in both countries, there are other differences in the rates of decline across goods. Food spending (both at home and away from home) declines more with age in the UK while transport and recreation spending decline more in the US.

\section{B. Precautionary Motives}

One omitted factor from our analysis so far is uncertainty over future medical expenditures which may well differ across the two countries, particularly as US households are exposed to a greater risk of high out of pocket medical expenses than UK households (as suggested by the distribution of expenditures presented in Table 2 above). A risk of having high medical expenditures should introduce a precautionary motive to delay consumption twisting consumption profiles in a way that reduces their initial level and gives them a less steep gradient (Carroll, 1997). By excluding medical expenses from the analysis we can control for differences in the level of such expenses across countries, but not for the effects that any differential variance in such expenses might have on other spending patterns.

The risk of incurring larger out of pocket medical expenses which are effectively absent in the UK but is likely to be an important consideration for US households - especially at older ages (Palumbo 1999, DeNardi et al. 2010). By excluding medical expenses from the analysis we can control for differences in the level of such expenses across countries, but not 
for the effects that any differential dispersion in such expenses might have on other spending patterns Other things equal this should imply that the profile of US spending excluding medical should be flatter than the profile for the UK. However, once other cross-country differences are controlled, the spending profiles in the two countries exhibit a difference of just over 0.2 percentage points.

To explain whether a greater demand for precautionary savings in the US could plausibly explain the magnitude of the smaller decline in expenditures for US households we need to get an idea of the scale of precautionary motives. A simple theoretical analysis, such as that in Banks et al. (2001), suggests that the effect of uncertainty over shocks to future medical expenses on consumption growth will depend on the product of three factors $k \pi_{t-1}^{2} \phi_{t}$ where $k$ is a constant scaling factor reflecting both the persistence of shocks and the consumer's risk aversion, $\pi_{\mathrm{t}-1}$ reflects the contribution of uncertainty in medical expenses to uncertainty in overall wealth (that can be approximated by ratio of medical expenses to nondurable consumption excluding medical in period $t-1)$ and $\phi_{t}$ is some measure of the dispersion in medical expenses conditional on information available to each individual consumer in period $t-1$. This dispersion measure should not include any predictable changes in medical expenses, as these do not generate precautionary motives.

Of the three factors, the a value for the $\pi_{t-1}$ weights can be readily estimated from our cross-sectional data (which we do using cohort level averages by education group). ${ }^{10}$ The choices of $k$ and $\phi_{t}$ are less straightforward. One approach is to estimate $\phi_{t}$ directly from our cohort data and then incorporate $\pi_{t-1}^{2} \phi_{t}$ in our regression analysis. This would allow us to identify the scale of precautionary effects using cohort variation in the importance of medical spending uncertainty.

As shown in Table 2, the distribution of OOP medical expenses in the US is highly positively skewed so that the main risk an individual faces is the relatively small but there exists a non-trivial risk of very high medical expenses. Thus to estimate this risk, we use the cohort, age and education specific difference in medical expenses at the $90^{\text {th }}$ percentile minus the median conditional on age, education group and cohort in the US. We then add this into the regression model in (1) and instrument it using its lag avoid the endogeneity of including a variable that includes $t-1$ consumption spending. ${ }^{11}$

\footnotetext{
${ }^{10}$ Specifically, the approximation to $\pi_{\mathrm{t}-1}$ is calculated as the square of the median ratio of medical expenditures to non-medical nondurable spending in each cohort-age-education cell.

${ }^{11}$ Calculating risk within cells defined by age, cohort and education eliminates important sources of this heterogeneity. Other sources of heterogeneity that lead to multiplicative differences between the conditional and
} 
The results for this exercise are reported in column (6) of Table 4. The uncertainty term enters with the expected positive coefficient but is imprecisely estimated. The unexplained difference between the two countries also switches sign, indicating that once precautionary savings motives are included, spending declines in the US appear too fast relative to the UK. The cross-county difference remains insignificant once uncertainty is added but falls by 0.3 to -0.13 percentage points (relative to the results in column (5)).

Overall, the role for medical uncertainty in explaining the differences in spending profiles between the two countries at these ages therefore appears small. There are a few possible explanations as to why this might be. One possibility is that precautionary motives do not produce reduced spending earlier in life but instead leads US households to increase their labor supply (Low (2005)). Such uncertainty would be expected to lead households to increase their employment worked prior to uncertainty being resolved (Floden (2006)). We control for this by including labor supply in our consumption growth analysis. The steeper declines in US incomes and tendency of US households to remain in employment longer (shown in Figures 1 and 4) would be consistent with such an explanation. A second possibility concerns the role of accumulated assets and intended bequests. Many American households in the age range we are considering have accumulated substantial amounts of wealth (Hurd and Smith, 2002). Bequest motives and avoidance of medical cost risk are two complimentary reasons for the size of this wealth accumulation. If these accumulated assets are used to finance large OOP medical costs, then the costs may be reflected through lower intended bequests rather than having to be absorbed through lower consumption. ${ }^{12}$

\section{Conclusions}

In this paper, we have compared consumption trajectories for older households in the UK and the USA. In the US, spending tends to remain relatively flat at older ages, while it declines quite steeply in the UK. This is despite that fact that other variables (employment, health and so on) tend to evolve in similar ways in both countries.

A key component in explaining this difference is medical spending, which rises in the US much faster than in the UK where medical expenses tend to be covered by the state.

unconditional risk (for example that might arise if lagged medical expenditures affect current spending through an autoregressive process) will be absorbed in the coefficient on $\pi_{\mathbf{t}-\mathbf{1}}^{\mathbf{2}} \boldsymbol{\phi}_{\mathbf{t}}$.

${ }^{12}$ A final possibility concerns the declining coverage of both the LCFS and the CEX relative to aggregate measures of spending in the National Accounts. For the definition of spending we are considering, this decline appears similar in the two countries (though it is slightly faster in the UK) as we discuss in Appendix C. 
Taking out medical spending from our comparison reduces the gap in the average decline in consumption spending by roughly three quarters. The remaining difference can be explained once other differences in the two countries in patterns of employment, health, housing and family size are controlled for.

These findings have relevance for discussions of consumption behavior at older ages. It is often found that older households, particularly in the US, tend to continue to amass wealth as they age (see for instance Love et al. (2009)). In this paper, we point out and account for differences between US households and households in an environment where the risks of high medical expenses have been effectively eliminated and for whom spending declines by much more. 


\section{REFERENCES}

Aguiar, Mark and Erik Hurst. 2005. "Consumption vs. Expenditure” Journal of Political Economy 113: 919-948.

Aguiar Mark and Erik Hurst. 2007. "Lifecycle Prices and Production” American Economic Review 97: 1533-59.

Aguiar Mark and Erik Hurst. 2013. "Deconstructing Lifecycle Expenditure” Journal of Political Economy 212: 437-92.

Banks, James, Richard Blundell, and Arthur Lewbel. 1997. "Quadratic Engel Curves and Consumer Demand." Review of Economics and Statistics 79: 527-39.

Banks, James, Richard Blundell, and Agar Brugiavini. 2001. "Risk Pooling, Precautionary Saving and Consumption Growth." Review of Economic Studies 68: 757-79.

Banks, James, Richard Blundell, and Sarah Tanner. 1998. "Is There a Retirement Savings Puzzle?" American Economic Review 88: 769-88.

Banks, James, Richard Blundell, Zoe Oldfield, and James P. Smith. 2012. "Housing Mobility and Downsizing at Older Ages in Britain and the USA." Economica 79: 1-26.

Banks, James, Richard Blundell, Zoe Oldfield, and James P. Smith. 2010. "Housing Price Volatility and Downsizing in Later Life." In Research Findings in the Economics of Aging, edited by David Wise, 337-86. Chicago: University of Chicago Press.

Banks, James, Michael Marmot, Zoe Oldfield, and James P. Smith. 2006. "Disease and Disadvantage in the United States and in England." Journal of the American Medical Association 295: 2037-45.

Barrett, Garry, Peter Levell and Kevin Milligan, "A comparison of micro and macro expenditure measures across countries using differing survey methods," in Christopher Carroll, Thomas F.Crossley and John Sabelhaus, Eds., Improving the Measurement of Consumer Expenditures, Studies in Income and Wealth, Volume 74. Chicago: University of Chicago Press, 2015.

Browning, Martin, Angus Deaton, and Margaret Irish. 1985. “A Profitable Approach to Labour Supply and Commodity Demands over the Life-Cycle.” Econometrica 53: 503-44.

Card, David, Carlos Dobkin, Nicole Maestas. 2009. "Does Medicare Save Lives.” Quarterly Journal of Economics 124: 597-636.

Carroll, Christopher. 1997. "Buffer-Stock Saving and the Life Cycle/Permanent Income Hypothesis." Quarterly Journal of Economics 112: 1-55. 
De Nardi, Mariacristina, Eric French, and John B. Jones. 2010. "Why Do the Elderly Save? The Role of Medical Expenses.” Journal of Political Economy 118: 39-75.

Deaton, Angus, and John Muellbauer. 1980. “An Almost Ideal Demand System.” American Economic Review 70: 312-26.

Finkelstein, Amy, Erzo Luttmer, and Matthew J. Notowidigdo. 2009. "What good is Wealth without Health? The Effect of Health on the Marginal Utility of Consumption." Journal of the European Economic Association 11: 221-58.

Finkelstein, Amy, Ezro Luttmer, and Matthew J. Notowidigdo. 2009. “Approaches to Estimating the Health State Dependence of the Utility Function.” American Economic Review 99: 116-21.

Flodén, Martin. 2006. "Labour Supply and Saving Under Uncertainty.” Economic Journal 116: $721-737$.

French, Eric, and John B. Jones. 2004. "On the Distribution and Dynamics of Health Care Costs." Journal of Applied Econometrics 19: 705-21.

Garner, Thesia, George Janini, William Passero, Laura Paskkiewicz and Mark Vendemia. 2006. "The CE and the PCE: a comparison", Monthly Labor Review, September: 2046.

Hurd, Michael, 1989. “Mortality Risk and Bequests.” Econometrica 57: 779-813.

Hurd, Michael and James P Smith, "Expected Bequests and Their Distribution," NBER Working Paper No. 9142, 2002

Lillard, Lee, and Yoram Weiss. 1997. "Uncertain Health and Survival: Effects on End-ofLife Consumption.” Journal of Business and Economic Statistics 15: 254-68.

Love, David A., Michael G. Palumbo, and Paul A. Smith. 2009. "The Trajectory of Wealth in Retirement.” Journal of Public Economics 93: 191-208.

Low, Hamish. 2005. "Self-insurance in a life-cycle model of labour supply and savings." Review of Economic Dynamics 8: 945-975.

Palumbo, Michael G. 1999. "Uncertain Medical Expenses and Precautionary Saving Near the End of the Life Cycle." Review of Economic Studies 66: 395-421.

Passero, William, Thesia Garner, and Clinton McCully, "Understanding the Relationship: CE Survey and PCE," in Christopher Carroll, Thomas F.Crossley and John Sabelhaus, Eds., Improving the Measurement of Consumer Expenditures, Studies in Income and Wealth, Volume 74. Chicago: University of Chicago Press, 2015.

Violante, Gianluca, ed. 2010. "Special Issue: Cross-Sectional Facts for Macroeconomists.” Review of Economic Dynamics, Volume 13, Issue 1. 


\section{Appendix A: The Within Period Demand System}

\section{A. A Model for Demand}

We run the following consumer demand model in each of the two countries:

$$
w_{i k}=\alpha_{i k}+\sum_{k}^{N} \gamma_{i k} \ln p_{k}+\beta_{k} \ln \left\{\frac{x_{i}}{a(p)}\right\}+\theta_{k} \ln \left\{\frac{x_{i}}{a(p)}\right\}^{2}
$$

where $w_{\mathrm{ik}}$ is the budget share of individual $i$ for each of the $N$ goods $k, p_{k}$ is the price of good $k$ and $x_{i}$ is total expenditure on the goods included in the demands system by individual $i$. There are $M$ demographic variables $z_{m i}$ for each individual $i$ including housing, employment, health and mortality are included in $\alpha_{i k}$

$$
\alpha_{i k}=\alpha_{k 0}+\sum_{k}^{M} \alpha_{m k} z_{m i}
$$

Expenditures are deflated using the price index

$$
\ln a(p)=\alpha_{O}+\sum_{k}^{N} \alpha_{k} \ln p_{k}+\frac{1}{2} \sum_{l}^{N} \sum_{k}^{N} \gamma_{l k} \ln p_{l} \ln p_{k}
$$

This model differs slightly from the Almost Ideal specification of Deaton and Muellbauer (1980) in that it includes an additional quadratic term on income (although it is still only an approximation to the fully integrable QUAIDS model (Banks et al. 1998)). Our interest is in establishing the nature of within-period non-separabilities between consumption and housing, health and employment in the two countries through the effect of these variables on household budget shares. By including total expenditure and prices, we control for differences in trends in relative prices and wealth across different birth cohorts in the two countries which may otherwise confound our estimates. The use of the household specific price index $a(p)$ means that income deflators can vary across groups according to their differing consumption patterns.

Prices for each of our categories are computed from the individual components and sub-indices of the UK Retail Price Index and the US CPI, which go back to 1978 and 1988 respectively. ${ }^{13}$ Typically, sub-indices are not available for the particular category grouping

\footnotetext{
${ }^{13}$ The authors are grateful to Brendan Williams of BLS for constructing price indices that go back to this date.
} 
we use (defined above in Table 1) so we calculate price indices in each cohort-year for each category $k$ using a Stone price index

$$
p_{k}=\exp \left(\sum_{j=1}^{N k} w_{j k} \log p_{j}\right)
$$

where $w_{j k}$ is the cohort-year budget share of good $j$ within some spending category $k$ for which there are $N k$ goods in category $k$ for which we want a price (e.g. "other nondurables").

We include sex, number of children, number of adults, and linear and quadratic time trends as controls in all models reported below. We also include dummies for being over state pension age in the UK (60 for women, 65 for men) and for being over 65 in the US. These are included to control for the effects of Medicare (to which US households become eligible at 65) and benefits such as free-prescriptions, the Winter Fuel Payment, and transport subsidies which UK households become eligible for at state pension age. We do not otherwise control for age - our view is that age is usually included as a proxy for health and mortality effects, and these are affects that we are directly interested in (and include separately). The health and mortality variables are cell averages for the population (by age, year and sex) based on the data we described in Section IV above. We instrument expenditure using income (dummying out changes in the income question in the CEX that occurred from the $2^{\text {nd }}$ quarter of $2001-$ introducing a bracketing question for those who failed to report their incomes - and income imputation which was introduced in 2004).

The coefficients of interest, $\alpha_{m k}$ are shown in Table A.1. The particular specification of the demographic variables, $z$, includes: (1) housing tenure with dummy variables for being a renter and housing owners with no mortgage so that the reference group are owners with remaining mortgages; (2) marital status represented a dummy variables for being single; (3) employment proxied by two dummies-household head employed and both partners working; (4) the log of mortality of the head (5) the health of head captured by a dummy for having the worst health status. 
Table A.1 Estimated Demand System Coefficients $\alpha_{m k}$

\begin{tabular}{|c|c|c|c|c|c|c|c|}
\hline & Food in & Food out & Othnd & Medical & Hrelated & Recrea & Transport \\
\hline \multirow[t]{2}{*}{ Mean Budget Shares (\%): } & \multicolumn{5}{|c|}{ UK (1978-2010) } & \multirow[b]{2}{*}{7.55} & \multirow[b]{2}{*}{13.1} \\
\hline & 23.80 & 5.12 & 25.46 & 1.85 & 23.15 & & \\
\hline Single & $\begin{array}{l}\mathbf{- 6 . 4 5} \\
(0.12)\end{array}$ & $\begin{array}{c}\mathbf{2 . 6 7} \\
(0.07)\end{array}$ & $\begin{array}{c}\mathbf{3 . 2 9} \\
(0.17)\end{array}$ & $\begin{array}{l}\mathbf{- 0 . 3 1} \\
(0.07)\end{array}$ & $\begin{array}{l}\mathbf{- 2 . 6 4} \\
(0.15)\end{array}$ & $\begin{array}{c}\mathbf{0 . 0 8} \\
(0.16)\end{array}$ & $\begin{array}{c}\mathbf{3 . 3 6} \\
(0.14)\end{array}$ \\
\hline Renter & $\begin{array}{c}\mathbf{0 . 7 9} \\
(0.09)\end{array}$ & $\begin{array}{c}\mathbf{0 . 3 7} \\
(0.05)\end{array}$ & $\begin{array}{c}\mathbf{3 . 3 5} \\
(0.13)\end{array}$ & $\begin{array}{l}\mathbf{- 0 . 0 7} \\
(0.05)\end{array}$ & $\begin{array}{l}\mathbf{- 4 . 0 0} \\
(0.11)\end{array}$ & $\begin{array}{c}\mathbf{0 . 3 3} \\
(0.12)\end{array}$ & $\begin{array}{c}\mathbf{- 0 . 7 8} \\
(0.10)\end{array}$ \\
\hline Own-outright & $\begin{array}{c}\mathbf{0 . 1 6} \\
(0.08)\end{array}$ & $\begin{array}{c}\mathbf{- 0 . 0 8} \\
(0.05)\end{array}$ & $\begin{array}{c}\mathbf{- 0 . 8 0} \\
(0.11)\end{array}$ & $\begin{array}{c}\mathbf{0 . 1 7} \\
(0.04)\end{array}$ & $\begin{array}{c}\mathbf{- 0 . 1 0} \\
(0.10)\end{array}$ & $\begin{array}{c}\mathbf{0 . 9 8} \\
(0.10)\end{array}$ & $\begin{array}{c}\mathbf{- 0 . 3 3} \\
(0.09)\end{array}$ \\
\hline Head-employed & $\begin{array}{l}\mathbf{- 0 . 0 5} \\
(0.09)\end{array}$ & $\begin{array}{c}\mathbf{0 . 6 2} \\
(0.05)\end{array}$ & $\begin{array}{l}\mathbf{- 0 . 4 0} \\
(0.12)\end{array}$ & $\begin{array}{c}\mathbf{0 . 0 2} \\
(0.05)\end{array}$ & $\begin{array}{l}\mathbf{- 0 . 8 1} \\
(0.10)\end{array}$ & $\begin{array}{l}\mathbf{- 0 . 4 5} \\
(0.11)\end{array}$ & $\begin{array}{c}\mathbf{1 . 0 6} \\
(0.10)\end{array}$ \\
\hline Both work & $\begin{array}{c}\mathbf{- 0 . 5 6} \\
(0.09)\end{array}$ & $\begin{array}{c}\mathbf{0 . 2 2} \\
(0.06)\end{array}$ & $\begin{array}{c}\mathbf{0 . 7 0} \\
(0.13)\end{array}$ & $\begin{array}{c}\mathbf{- 0 . 1 4} \\
(0.05)\end{array}$ & $\begin{array}{c}\mathbf{- 0 . 5 7} \\
(0.11)\end{array}$ & $\begin{array}{c}\mathbf{0 . 4 9} \\
(0.12)\end{array}$ & $\begin{array}{c}\mathbf{- 0 . 1 4} \\
(0.11)\end{array}$ \\
\hline $\ln ($ mortality) & $\begin{array}{c}\mathbf{1 . 0 0} \\
(0.07)\end{array}$ & $\begin{array}{l}\mathbf{- 0 . 0 7} \\
(0.04)\end{array}$ & $\begin{array}{l}\mathbf{- 1 . 7 2} \\
(0.10)\end{array}$ & $\begin{array}{c}\mathbf{0 . 3 1} \\
(0.04)\end{array}$ & $\begin{array}{c}\mathbf{0 . 6 0} \\
(0.08)\end{array}$ & $\begin{array}{c}\mathbf{0 . 1 8} \\
(0.09)\end{array}$ & $\begin{array}{c}\mathbf{- 0 . 3 0} \\
(0.08)\end{array}$ \\
\hline Worst health & $\begin{array}{c}\mathbf{- 0 . 4 0} \\
(0.52)\end{array}$ & $\begin{array}{l}\mathbf{- 0 . 8 7} \\
(0.32)\end{array}$ & $\begin{array}{l}\mathbf{- 0 . 5 7} \\
(0.73)\end{array}$ & $\begin{array}{c}\mathbf{- 0 . 0 2} \\
(0.28)\end{array}$ & $\begin{array}{c}-\mathbf{- 0 . 2 0} \\
(0.62)\end{array}$ & $\begin{array}{c}\mathbf{1 . 1 1} \\
(0.64)\end{array}$ & $\begin{array}{c}\mathbf{0 . 9 5} \\
(0.56)\end{array}$ \\
\hline Constant & $\begin{array}{l}\mathbf{6 0 . 1 2} \\
(0.66)\end{array}$ & $\begin{array}{c}\mathbf{- 5 . 9 3} \\
(0.40)\end{array}$ & $\begin{array}{l}\mathbf{- 2 . 0 3} \\
(0.93)\end{array}$ & $\begin{array}{c}\mathbf{0 . 9 8} \\
(0.35)\end{array}$ & $\begin{array}{l}\mathbf{5 9 . 3 7} \\
(0.79)\end{array}$ & $\begin{array}{l}\mathbf{- 2 . 5 5} \\
(0.84)\end{array}$ & $\begin{array}{c}\mathbf{- 9 . 9 7} \\
(0.76)\end{array}$ \\
\hline
\end{tabular}

\begin{tabular}{lccccccc}
\hline \multicolumn{7}{l}{ Mean Budget Shares (\%): } & \multicolumn{7}{c}{ US (1988-2010) } \\
& 21.99 & 6.66 & 18.21 & 11.80 & 19.74 & 4.41 & 17.20 \\
\hline Single & $\mathbf{- 4 . 6 7}$ & $\mathbf{3 . 0 9}$ & $\mathbf{2 . 1 0}$ & $\mathbf{- 3 . 3 5}$ & $\mathbf{- 0 . 6 4}$ & $\mathbf{1 . 3 2}$ & $\mathbf{2 . 1 7}$ \\
& $(0.26)$ & $(0.16)$ & $(0.26)$ & $(0.38)$ & $(0.25)$ & $(0.14)$ & $(0.24)$ \\
Renter & $\mathbf{- 0 . 0 9}$ & $\mathbf{2 . 2 0}$ & $\mathbf{4 . 7 8}$ & $\mathbf{0 . 3 9}$ & $\mathbf{- 1 0 . 1 4}$ & $\mathbf{1 . 4 5}$ & $\mathbf{1 . 4 5}$ \\
& $(0.27)$ & $(0.18)$ & $(0.27)$ & $(0.39)$ & $(0.27)$ & $(0.15)$ & $(0.25)$ \\
Own-outright & $\mathbf{0 . 0 3}$ & $\mathbf{0 . 5 5}$ & $\mathbf{- 0 . 6 3}$ & $\mathbf{0 . 6 5}$ & $\mathbf{- 0 . 4 9}$ & $\mathbf{0 . 1 0}$ & $\mathbf{- 0 . 2 1}$ \\
& $(0.14)$ & $(0.08)$ & $(0.14)$ & $(0.21)$ & $(0.13)$ & $(0.07)$ & $(0.13)$ \\
Head-empl. & $\mathbf{0 . 9 8}$ & $\mathbf{0 . 4 6}$ & $\mathbf{- 0 . 5 8}$ & $\mathbf{- 1 . 6 9}$ & $\mathbf{0 . 0 8}$ & $\mathbf{- 0 . 3 4}$ & $\mathbf{1 . 0 8}$ \\
& $(0.19)$ & $(0.12)$ & $(0.19)$ & $(0.28)$ & $(0.19)$ & $(0.10)$ & $(0.18)$ \\
Both work & $\mathbf{- 2 . 0 1}$ & $\mathbf{0 . 4 3}$ & $\mathbf{1 . 2 6}$ & $\mathbf{- 0 . 1 1}$ & $\mathbf{- 0 . 8 6}$ & $\mathbf{0 . 3 0}$ & $\mathbf{1 . 0 1}$ \\
& $(0.19)$ & $(0.12)$ & $(0.18)$ & $(0.27)$ & $(0.18)$ & $(0.10)$ & $(0.17)$ \\
ln(mortality) & $\mathbf{- 0 . 3 1}$ & $\mathbf{- 0 . 4 8}$ & $\mathbf{- 1 . 8 5}$ & $\mathbf{2 . 5 4}$ & $\mathbf{1 . 0 1}$ & $\mathbf{- 0 . 0 8}$ & $\mathbf{- 0 . 8 3}$ \\
& $(0.14)$ & $(0.09)$ & $(0.14)$ & $(0.22)$ & $(0.14)$ & $(0.07)$ & $(0.13)$ \\
Worst health & $\mathbf{- 0 . 2 3}$ & $\mathbf{- 0 . 2 0}$ & $\mathbf{2 . 6 4}$ & $\mathbf{- 0 . 9 7}$ & $\mathbf{- 1 . 9 8}$ & $\mathbf{- 0 . 8 6}$ & $\mathbf{1 . 6 3}$ \\
& $(0.67)$ & $(0.41)$ & $(0.67)$ & $(1.01)$ & $(0.66)$ & $(0.35)$ & $(0.62)$ \\
Constant & $\mathbf{4 7 . 2 3}$ & $\mathbf{- 5 . 0 4}$ & $\mathbf{2 . 1 3}$ & $\mathbf{2 1 . 4 2}$ & $\mathbf{3 8 . 9 1}$ & $\mathbf{- 4 . 2 1}$ & $\mathbf{- 0 . 6 2}$ \\
& $(1.33)$ & $(0.86)$ & $(1.32)$ & $(1.89)$ & $(1.31)$ & $(0.73)$ & $(1.23)$ \\
\hline UK N=89,268; US N= 46,070, standard errors in parentheses. We take only data from the first interview in the \\
CEX. Additional controls for log expenditure, log expenditure squared, number of children, number of adults, \\
dummy for whether head or spouse has compulsory education, a quadratic time trend, being over state pension \\
age and self-reported health missing. Expenditure is instrumented using income (with additional dummies in \\
US model for year greater than 2001 and year greater than 2004, when changes to the survey income questions \\
were introduced).
\end{tabular}


Appendix B: Country Regressions

Table B.1. Change in Log Nondurable Expenditure by Country (Including Medical)

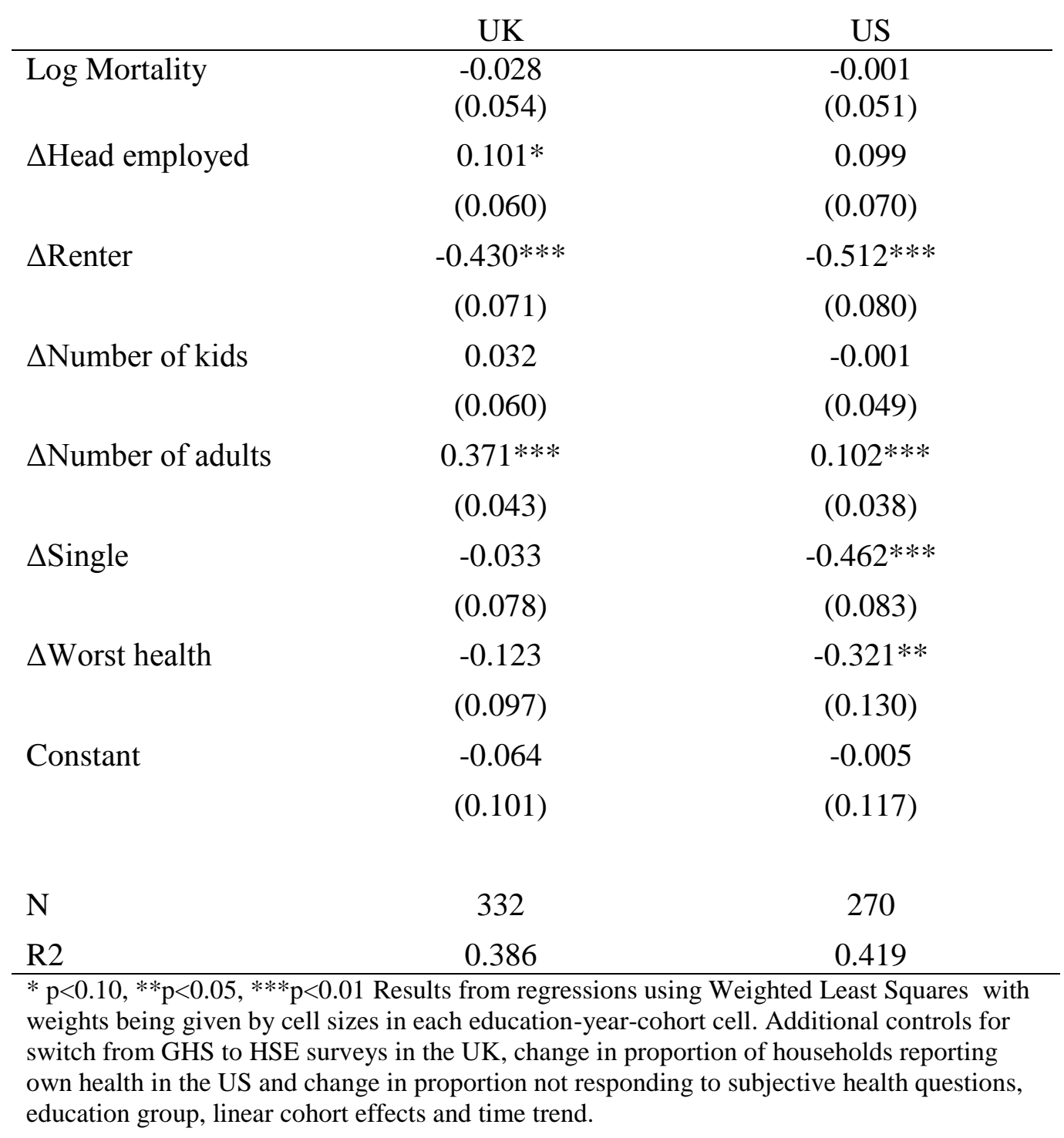


Table B.2. Change in Log Nondurable Expenditure by Country (Excluding Medical)

\begin{tabular}{lcc}
\hline & UK & US \\
\hline Log Mortality & -0.030 & -0.011 \\
$\Delta$ Head employed & $(0.055)$ & $(0.053)$ \\
& 0.099 & 0.121 \\
$\Delta$ Renter & $(0.061)$ & $(0.074)$ \\
& $-0.440 * * *$ & $-0.529 * * *$ \\
$\Delta$ Number of kids & $(0.072)$ & $(0.084)$ \\
& 0.043 & 0.010 \\
$\Delta$ Number of adults & $(0.060)$ & $(0.051)$ \\
& $0.369 * * *$ & $0.114 * * *$ \\
$\Delta$ Single & $(0.044)$ & $(0.039)$ \\
& -0.027 & $-0.402 * * *$ \\
$\Delta$ Worst health & $(0.079)$ & $(0.087)$ \\
Constant & -0.108 & $-0.316 * *$ \\
& $(0.098)$ & $(0.136)$ \\
N & -0.070 & -0.044 \\
R2 & $(0.102)$ & $(0.122)$ \\
\hline
\end{tabular}

$* \mathrm{p}<0.10, * * \mathrm{p}<0.05, * * * \mathrm{p}<0.01$ Results from regressions using Weighted Least Squares with weights being given by cell sizes in each education-year-cohort cell. Additional controls for switch from GHS to HSE surveys in the UK, change in proportion of households reporting own health in the US and change in proportion not responding to subjective health questions, education group, linear cohort effects and time trend. 
Table B.3. Average Change in Log Consumption by Category

\begin{tabular}{lccc}
\hline & UK & US & US-UK \\
\hline Food in & $-2.698^{* * *}$ & $-1.705^{* * * *}$ & $0.993^{* *}$ \\
& $(0.355)$ & $(0.298)$ & $(0.463)$ \\
Food out & $-2.339 * * *$ & -0.848 & 1.491 \\
& $(0.794)$ & $(0.666)$ & $(1.036)$ \\
Other non-durables & $-3.724 * * *$ & $-3.947 * * *$ & -0.224 \\
& $(0.450)$ & $(0.377)$ & $(0.587)$ \\
Medical & $1.300^{*}$ & $3.526 * * *$ & $2.227 * *$ \\
& $(0.705)$ & $(0.591)$ & $(0.920)$ \\
Housing related & -0.212 & -0.128 & 0.084 \\
& $(0.388)$ & $(0.325)$ & $(0.506)$ \\
Recreation & -0.164 & $-2.718 * * *$ & $-2.554 *$ \\
Transport & $(1.021)$ & $(0.856)$ & $(1.332)$ \\
& $-1.601 * *$ & $-2.130 * * *$ & -0.528 \\
& $(0.650)$ & $(0.545)$ & $(0.849)$ \\
\hline
\end{tabular}

$* \mathrm{p}<0.10, * * \mathrm{p}<0.05, * * * \mathrm{p}<0.01$. Results from regressions using Weighted Least Squares with weights being given by cell sizes in each education-year-cohort cell 


\section{Appendix C: Coverage of Household Surveys}

Comparisons of both the LCFS and the CEX to the aggregate National Income and Product Accounts (NIPA) in the respective countries have highlighted the possibility of increasing measurement error in the two surveys. It is now well-documented that coverage rates (the proportion of consumer expenditure in the national accounts that is accounted for by the household surveys) have been declining in both the US and UK (see for example Passero et al. (2015) and Attanasio et al. (2006)). This potentially has consequences for our estimates of consumption growth. In this appendix we compare trends in coverage rates for the two countries to understand better what the implications of this might be.

Any comparison of national account and survey data must take into account the fact that the two measure different spending concepts. For example, the two sources cover different populations. Both the LCFS and the CEX exclude foreign residents, and those in institutional residences whose spending is included in NIPA. In addition, some items of spending that may be thought of as taxes are included as expenditures in surveys but are counted as transfers rather than expenditures in the NIPA. Finally, there are items for which the definitions of spending differ. For example, the NIPA impute rental costs to homeowners owner-occupiers while not including the outgoings on for example mortgage interest payments. In the US spending on healthcare made on behalf of households by employers and the government (including the Medicare and Medicaid programs) are also counted as household spending in the NIPA but are not counted in the CEX.

In what follows, we calculate coverage rates after first making adjustments to both our survey data and to the NIPA to make them more comparable. We start by removing spending by non-profit institutions on households behalf from the personal consumption expenditures in both the UK and the US. We then exclude spending on imputed rent to owner-occupiers in the NIPA. In our surveys we remove the costs of mortgage interest, vehicle licensing costs, property taxes and (in the UK) TV licenses. We also show the consequences of removing health spending from both sources. ${ }^{14}$

\footnotetext{
${ }^{14}$ Passero et al. (2015) make more detailed adjustments to spending in the CEX and US national accounts in order to make a similar comparison. In particular they also make adjustments for the different treatment of used vehicles, financial service charges, owner-occupied shelter costs and certain insurance premiums. Without access to more disaggregated national account data we cannot make these adjustments in the UK however, and so leave the US data unadjusted in order to make the resulting coverage rates consistent. As a result the figures presented here will differ slightly from those in Passero et al.
} 
Figure C.1 plots the coverage rates for total expenditure, nondurables, nondurables excluding medical expenditures and durables.
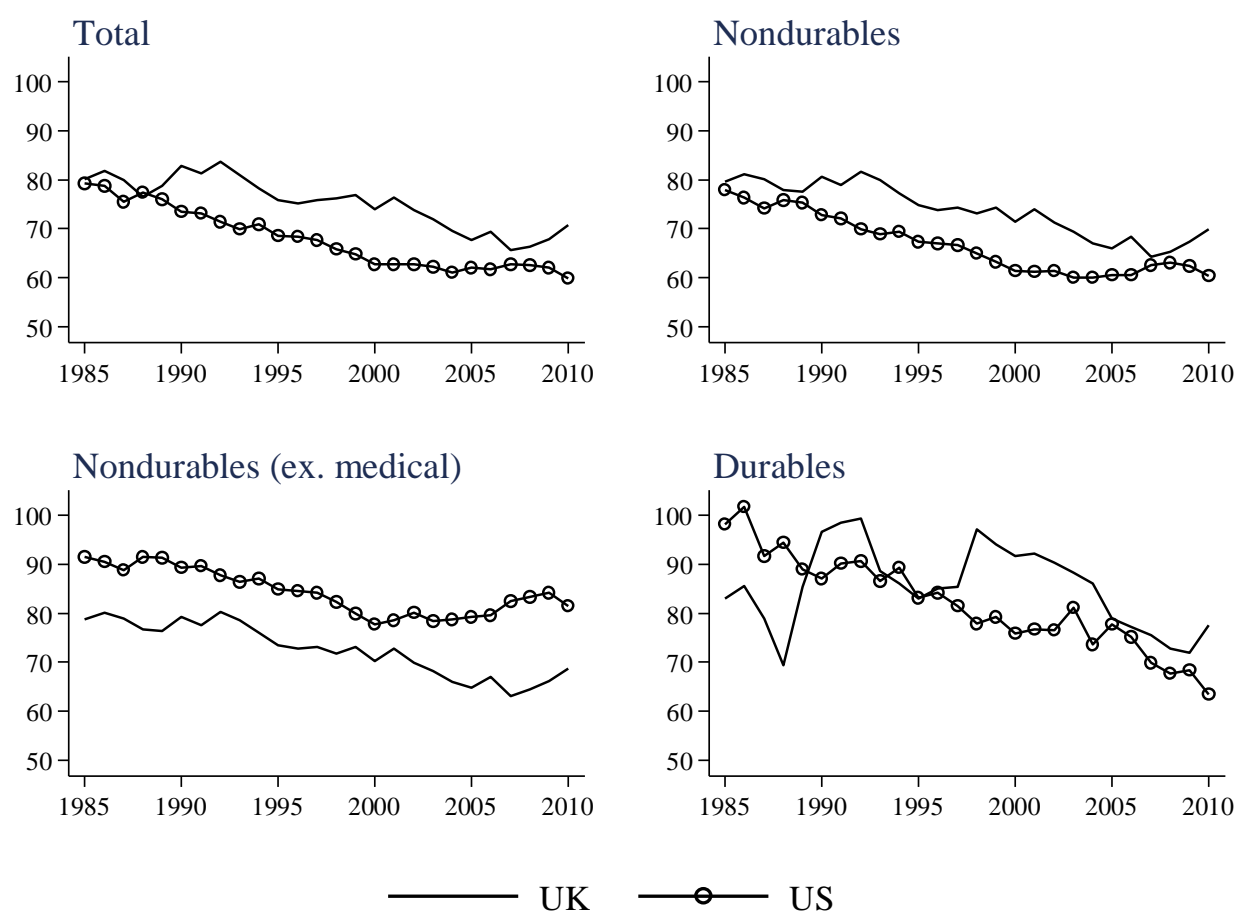

Figure C.1 Coverage Rates, 1985-2010

Note: Coverage rate is the proportion of consumer expenditure in the national accounts that is accounted for in the household surveys. Household survey data comes from the LCFS in the UK and the CEX in the US. National Income and Product Account (NIPA) data comes from the UK Office for National Statistics and the US Bureau of Economic Analysis.

The first thing to notice is that there is evidence of a steady decline in coverage in both countries. The top left panel shows coverage rates for total spending (including medical) which decline faster in the UK than the US. ${ }^{15}$ These fall from $80 \%$ to $71 \%$ in the UK over the period 1985-2010 compared to a fall from $80 \%$ to $60 \%$ in the US. A decline in coverage of this magnitude would reduce annual spending growth as measured in surveys by around 0.5 percentage points in the UK compared to 1.2 percentage points in the US. ${ }^{16}$

\footnotetext{
15 This differs from a similar figure (Figure 9.1) in Barrett et al. (2015). The primary difference is that medical spending is not removed from total spending here but is removed in Barrett et al.

${ }^{16}$ These figures are obtained by taking the proportional change in coverage (i.e. coverage in 2010/coverage in 1985 ) to the power $1 / 25$. If the answer for this calculation is $1-x$, this would tell us that a reduction in the amount of spending captured in the household survey of $x \%$ each year from 1985-2010 would result in the decline in coverage we observe.
} 
The coverage rates of nondurable spending, which is the definition of spending examined in this paper, decline at similar rates. However, when we remove health spending in the bottom left panel, the picture is very different. Coverage rates are now higher in the US (where they fall from $91 \%$ to $82 \%$ ) than the UK (where the fall is from $79 \%$ to $69 \%$ ). The implied falls would now suggest a slightly larger understatement of spending growth in the UK (by 0.54 percentage points compared to 0.46 percentage points in the US). The difference that arises from excluding healthcare reflects the rapid growth of medical spending on US households by government and employers. As mentioned above these expenditures are not included as household spending in the CEX survey but are included in the US NIPA. Passero et al. (2015) estimate that spending by government on behalf of households in the US increased by 271 percent from 1992 to 2010 and that this accounts for one fourth of the growth in the gap between the coverage of the CEX survey and NIPA consumption spending. An additional proportion is likely to be explained by growth in the proportion of health costs paid by employers. In the UK spending on the NHS is not attributed to households in the national accounts in the same way, and employer coverage is much less widespread. As a result, excluding health spending has a much smaller effect on coverage rates in the UK.

Durable spending in our household surveys has higher rates of coverage in both countries. The CEX accounted for roughly $100 \%$ of the durable spending in the national accounts by our measure in the US in 1985 . This fell to just $63 \%$ in 2010 . In the UK the decline was from $83 \%$ to $77 \%$ over the same period. 